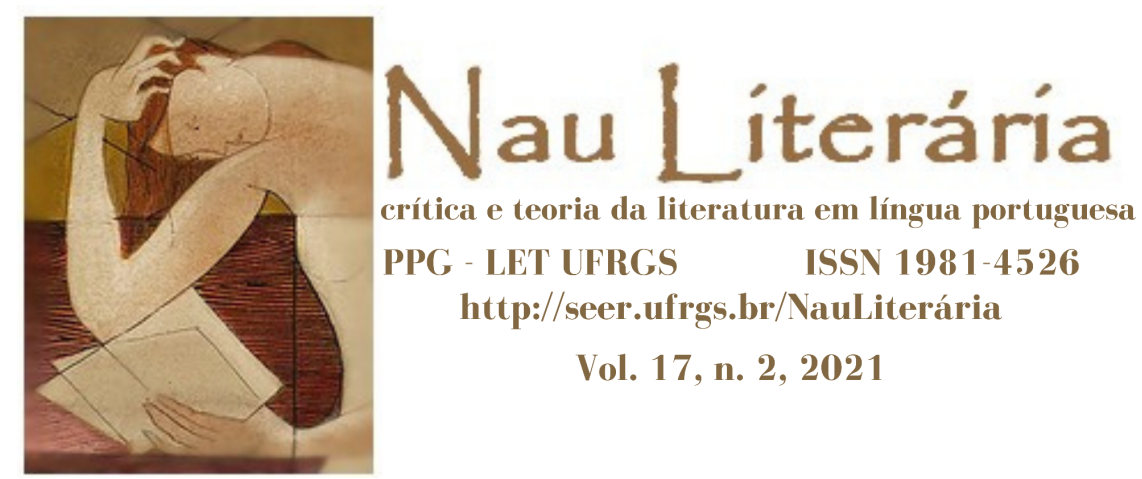

\title{
O tempo agora é moeda: de Balzac a Graciliano Ramos
}

\author{
Time is money now: from Balzac to Graciliano Ramos
}

\section{Leilane Luiza Ferreira Mota ${ }^{1}$ \\ Emílio Maciel $^{2}$}

\begin{abstract}
Resumo: A frase "tempo é dinheiro" torna-se muito comum a partir do século XVIII com a Revolução Industrial. Os donos de fábricas passaram a controlar o tempo e a propagar a ideia de que seu uso deveria ser feito com a máxima eficiência para evitar desperdícios. No século XIX, com o surgimento da classe burguesa, o controle e a disciplina do tempo tornam-se valores fundamentais. Junta-se à nova percepção temporal uma forma mais democrática e horizontal no tratamento das pessoas inaugurada pela Revolução Francesa. A partir desse momento, a fixidez de papéis sociais se dilui e o povo passa de objeto a sujeito da história. Consequentemente, surge uma nova concepção de identidade, que se torna mais fragmentada, $\mathrm{e}$, ao mesmo tempo, mais subordinada às ações do sujeito do que à vida social. Todos esses temas perpassam a obra de Balzac. Pretende-se demonstrar, neste artigo, que São Bernardo, de Graciliano Ramos, seria um modelo reduzido que comprimiria tanto o romance do século XIX quanto o romance do século XX, por retomar daquele certos temas principais, como o self-made man e os impasses da mobilidade social, e deste a tensão do efeito corrosivo do tempo.
\end{abstract}

Palavras-chave: tempo; dinheiro; democracia; identidade; romance.

\begin{abstract}
The phrase "time is money" became very common in the $18^{\text {th }}$ century because of the Industrial Revolution. Owners of industries started disseminating the idea that time must be counted and used with most efficiency possible so there would be no waste of it. In the $19^{\text {th }}$ century, along with the arising bourgeoisie time management became a fundamental quality. A more democratic and horizontal manner of dealing with people is also added to this new perception of time. From this moment on, the fixity of social roles weakens and people go from object to subject of the history. Consequently, a new conception of identity, which becomes more fragmentated and at the same time more subordinated to the subject actions rather than to social life, emerges. All theses themes are present in Balzac's works. This paper aims to demonstrate that Graciliano Ramos' São Bernardo is a summarized paradigm of it, since it retrieves from the $19^{\text {th }}$ century romance topics such as the idea of the "self-made man" and the impasses for social mobility and from the $20^{\text {th }}$ century romance issues related to the tension derived from time's corrosive effect.
\end{abstract}

Keywords: time; money; democracy; identity; novel.

\footnotetext{
${ }^{1}$ Mestra pelo Programa de Pós-graduação em Letras: Estudos da Linguagem da Universidade Federal de Ouro Preto.

${ }^{2}$ Professor doutor associado ao Departamento de Letras da Universidade Federal de Ouro Preto.
} 


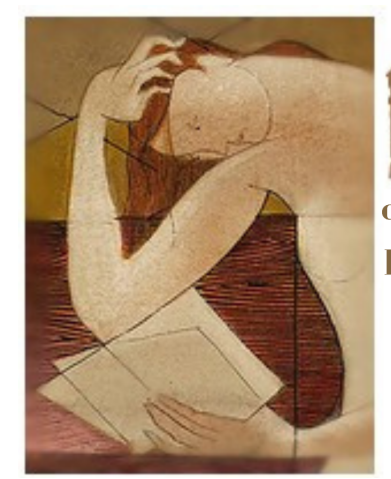

\section{Nau Literáría \\ crítica e teoria da literatura em língua portuguesa \\ PPG - LET UFRGS ISSN 1981-4526 \\ http://seer.ufrgs.br/NauLiterária \\ Vol. 17, n. 2, 2021}

[Rastignac] Tirou o relógio do bolso e admirou-o.

- Tudo tem me saído bem! Quando se ama para sempre, a gente pode se ajudar, e assim posso aceitar isto. Certamente vencerei na vida e poderei retribuir-lhe tudo centuplicado. (BALZAC, 2012, p. 231)

Assisti um dia destes a uma fita no cinema, e creio que aprendi mais que se visse aquilo escrito. Sem contar que gasta menos tempo. (RAMOS, 1990, p. 92)

\section{O pai Goriot e São Bernardo: duas faces da mesma moeda?}

Em um texto sobre Madame Bovary, o crítico francês Armand de Portmartin (1860, p. 321-322 apud RANCIÈRE, 2017, p. 23) discorre acerca do que considera ser um dos aspectos mais chamativos do romance de Flaubert: os acontecimentos significantes são igualados aos insignificantes. O que o crítico vê como um aspecto chamativo, Jacques Rancière verá, em $O$ fio perdido, como a grande virada da ficção moderna. Ele explora o conceito de "democracia na literatura", ou "democracia das sensações", de Portmartin, para compreender como o romance moderno promove a igualdade entre todas as coisas, sejam elas pessoas ou sensações.

A proliferação de personagens secundárias no romance serviria justamente para mostrar essa igualdade. A indistinção entre almas de elite e almas de ferro, que já vinha sendo feita nos romances do início do século XIX, sobretudo na literatura produzida por Balzac, tem seu ápice em Madame Bovary. Os elementos satélites, ou seja, os elementos secundários que serviriam para emoldurar a ação principal, portanto, assumem o lugar do cerne da narrativa. Podemos dizer que, de um modo geral, a literatura do século XX lida com essa inversão: o elemento irrelevante que se torna essencial.

Na passagem da literatura do século XIX para o século XX, outro aspecto que muda é o modo de tratar do tempo. No século XIX, o tempo está em consonância com o modo de vida burguês e, com o auge da expansão do capitalismo, a máxima "tempo é dinheiro", retomando o lema de Benjamin Franklin (1748, p. 87 apud WEBER, 2004, p. 42), está por toda parte. Balzac insere-se nesse período e explora esse tema em várias obras da Comédia humana, 


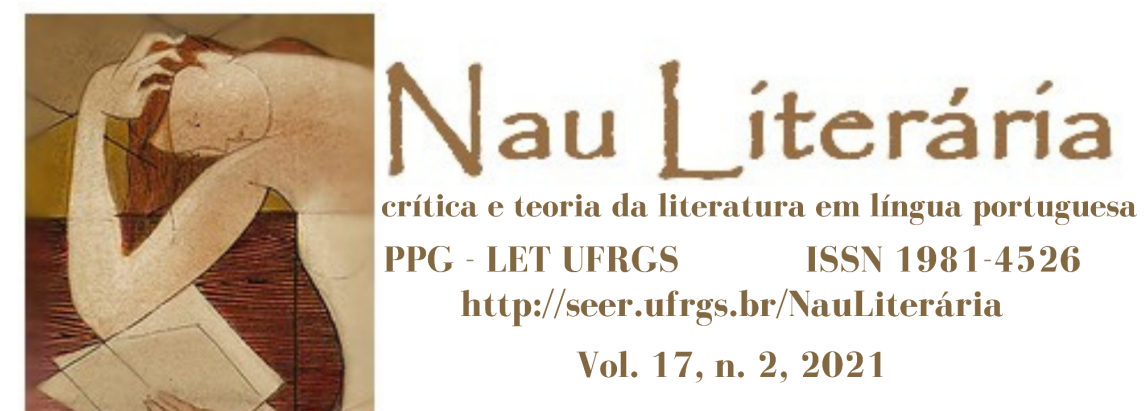

sobretudo em O pai Goriot. O romance São Bernardo, de Graciliano Ramos, além de recuperar o motor da obra balzaquiana, coloca em destaque o efeito de corrosão do tempo no sujeito. Ainda que Balzac trabalhe também com a corrosão da energia vital por meio de Rastignac, o momento decisivo no fím do romance dá ao estudante forças para desafiar a sociedade. Paulo Honório, ao contrário, é vencido pelo tempo no final da narrativa.

Essa revalorização dos elementos mínimos e a nova forma de tratar do tempo têm incidência direta na transformação da identidade do sujeito e no reconhecimento de que ela é instável. Todos esses temas só poderiam ser tratados no gênero romanesco graças ao evento que possibilitou transformações profundas em nossa sociedade em todas as esferas: a Revolução Francesa.

Os romances escolhidos para análise neste artigo lidam com essas questões, de formas distintas, é claro, mas percebemos que São Bernardo faz uma compressão desses temas da literatura do século XIX, misturando-os e mostrando seus pontos cegos no século XX. Além disso, uma retomada nos chama a atenção: a figura do self-made man. Essa figura, característica do século XIX, e, portanto, do romance de Balzac, por meio de seus arrivistas, como Rastignac, é encarnada em Paulo Honório com a função de mostrar sua crise no século XX.

\section{2 “Tempo é dinheiro": do século XIX ao século XX}

Moretti (2014), em O burguês, analisa os "momentos decisivos" e os "enchimentos" no romance do século XIX, a partir dos conceitos apresentados por Barthes (1983, p. 265-266 apud MORETTI, 2014, p. 76) em "Introdução à análise estrutural narrativa". Os momentos decisivos são os momentos principais da trama e os enchimentos se dão entre os momentos decisivos, que abrem uma alternativa com consequências que possibilitam o andamento da trama. Os enchimentos são parasitários a esses momentos e não têm o poder de modificar essas alternativas. 


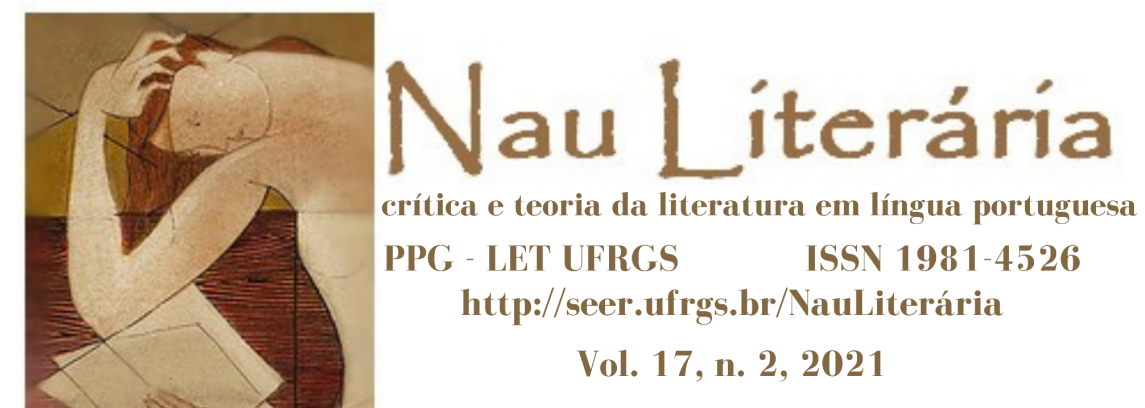

Dando maior atenção aos enchimentos no romance, o autor relaciona-os ao modo de vida burguês. Moretti afirma que os enchimentos são momentos de narração no romance, mas são narração do cotidiano e é justamente nesse ponto que se encontra o seu segredo. Os enchimentos funcionam, em certo aspecto, de forma bem parecida com as boas maneiras, que são "[...] tão caras aos romancistas do século XIX [...]" (MORETTI, 2014, p. 78): são um mecanismo que serve para manter a "[...] 'narratividade' da vida sob controle [...]" (MORETTI, 2014, p. 78), conferindo à vida uma regularidade, um “estilo".

O motivo de haver enchimentos na literatura e na arte do século XIX encontra-se fora dessas áreas, de acordo com Moretti; ele está na própria vida privada burguesa, na sala de estar, que é um “[...] espaço aberto porém protegido, pronto para gerar uma nova história a cada dia. Mas uma história permeada pela crescente regularidade da vida privada." (MORETTI, 2014, p. 87). A regularidade tem relação com certos valores da classe burguesa emergente, como trabalho, horários, hábitos e rotina. É a vida burguesa ligada ao relógio e ao cronômetro.

Os enchimentos "[...] propiciam um prazer narrativo compativel com a nova regularidade da vida burguesa. Eles são para a narração o que os confortos são para o prazer físico: diversão amenizada, adaptada à atividade diária de ler um romance." (MORETTI, 2014, p. 88). Eles são também

[...] pequenas coisas [que] se tornam significantes sem deixar de ser "pequenas", tornam-se narrativa sem deixar de ser cotidiano. A difusão dos enchimentos transforma o romance em uma "paixão serena", para reiterar o formidável oximoro de Hirschmann sobre o interesse econômico [...]. (MORETTI, 2014, p. 88-89)

Os detalhes, então, tornam-se importantes sem deixar de serem detalhes. A "paixão serena" da personagem do romance está relacionada diretamente à disciplina, ao controle, ao tempo burguês e à perseverança da personagem em relação aos seus desejos, ainda que haja um esfriamento de sua vontade, como veremos nos romances em questão, sobretudo em São Bernardo. A disciplina burguesa funciona justamente como um modo de apaziguar o desejo da personagem. Nota-se que a "paixão serena" relaciona-se também com o dinheiro, visto que 


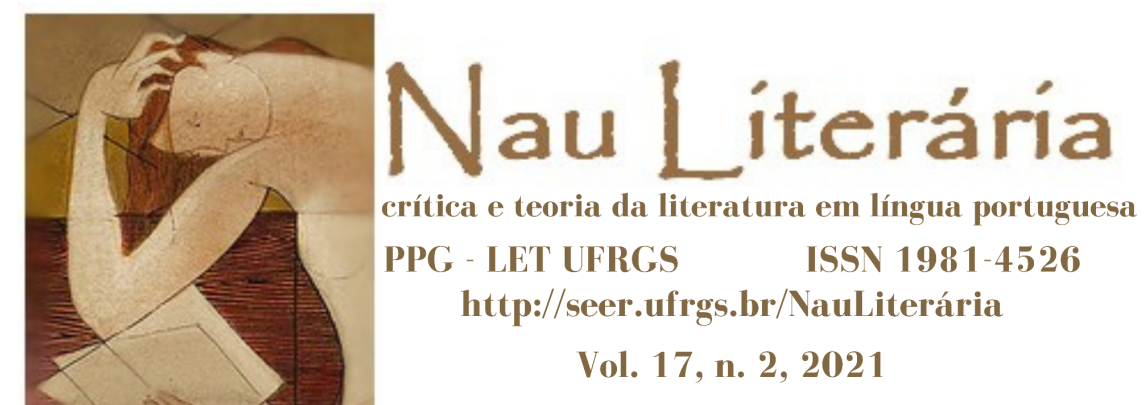

o oximoro surge ligado à economia. Esse oximoro aponta para a ideia de que o mundo burguês é como um livro de partidas dobradas, que é um mecanismo para contabilizar o saldo positivo e o saldo negativo, em que cada evento é avaliado segundo seus efeitos, assim como Carlos Drummond de Andrade escreve em "Elegia": "Ganhei (perdi) meu dia." (ANDRADE, 2001, p. 336).

Paulo Honório, em São Bernardo, realiza essa contabilidade ao narrar sua vida no romance. Ao pesar na balança seus saldos, no último capítulo do romance, ele se dá conta de que o saldo negativo prevalece em comparação ao positivo:

De longe em longe sento-me fatigado e escrevo uma linha. Digo em voz baixa:

- Estraguei a minha vida estupidamente.

Penso em Madalena com insistência. Se fosse possível recomeçarmos... Para que enganar-me? Se fosse possível recomeçarmos, aconteceria exatamente o que aconteceu. Não consigo modificar-me, é o que mais me aflige. (RAMOS, 1990, p. 184-187, grifos nossos)

Neste trecho, além do aparecimento do cansaço, do qual falamos anteriormente, Paulo Honório conclui que o estrago que ele mesmo fez à sua vida é irreversível. Ainda que abra a possibilidade de um recomeço de sua vida com Madalena, ele sabe que isso não pode acontecer porque, no momento em que esse trecho é narrado, ela já está morta. Paulo Honório conclui que as coisas são exatamente como devem ser e marca o saldo negativo no balanço de sua vida. Um detalhe muito importante, que também nos chama a atenção, é a definição de sua identidade. Se, como veremos, o narrador tenta diversas vezes definir-se ao longo do romance, no final do livro ele impõe que o grande problema é que sua identidade está cristalizada e é disso que ele tem medo. Contudo, o movimento que percebemos no romance vai totalmente contra à conclusão de Paulo Honório, justamente devido às diversas tentativas definição que faz de si próprio e a corrosão de sua vontade também pode contribuir para a percepção desse movimento.

A seriedade, típica da classe burguesa em ascensão, é relacionada, por Moretti, tanto à regularidade da vida burguesa quanto ao dinheiro e à "paixão serena", enquanto forma de contabilidade de saldos, que rege a vida comercial: 


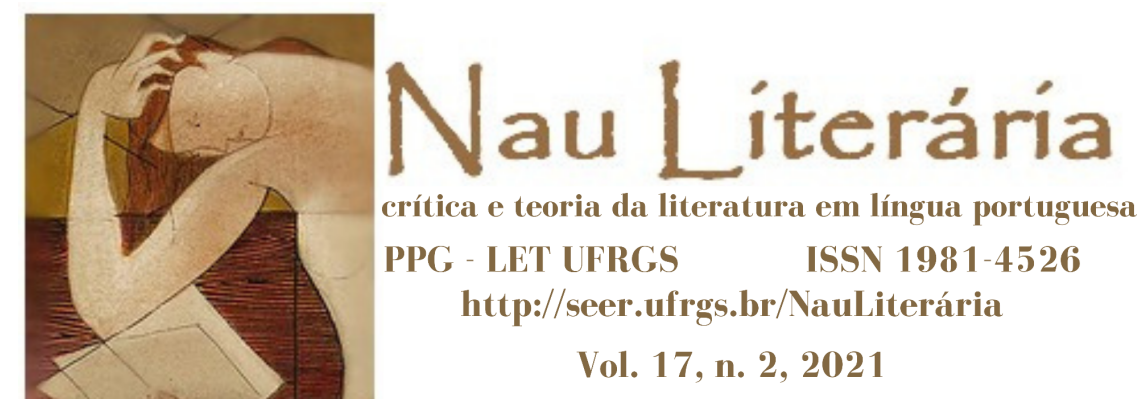

Para além da compostura ética e da compenetração profissional do especialista, a seriedade surge aí como uma espécie de honestidade comercial engrandecida [...], estendida para a vida como um todo: confiabilidade, método, exatidão, "ordem e clareza", realismo. No sentido mesmo do princípio de realidade, em que aceitar a realidade passa a ser, mais do que uma necessidade constante, um "princípio", um valor. Conter desejos não é apenas repressão: é cultura. (MORETTI, 2014, p. 93)

Assim como na definição de realismo de Auerbach ("imitação séria do cotidiano"), o autor liga o cotidiano, enquanto aspecto que abrange toda a sociedade, ao temperamento sério da burguesia. Nesse sentido, a disciplina, o método, a regularidade e a precisão tornam-se os valores que guiam toda a sociedade burguesa do século XIX. O apaziguamento das paixões não é somente repressão, segundo o autor, é cultura.

Referindo-se a uma cultura que foge completamente dos valores burgueses, Evans-Pritchard, em Os Nuer, analisa o tempo e o espaço nessa tribo. As concepções de tempo e de espaço dos nuer são ligadas às atividades cotidianas e às interações sociais. As atividades realizadas são as mesmas durante todo o ano, mas o valor que se dá ao tempo é diferente: ele depende do espaço em que a tribo esteja em determinadas épocas do ano. A conclusão à qual o autor chega nos é preciosa. Os nuer não possuem uma expressão equivalente a "tempo". Dessa forma, o tempo para eles não é algo concreto e não pode ser medido ou controlado:

Embora eu tenha falado em tempo e unidades de tempo, os Nuer não possuem uma expressão equivalente ao "tempo" de nossa língua e, portanto, não podem, como nós podemos, falar de tempo como se fosse algo concreto, que passa, pode ser perdido, pode ser economizado, e assim por diante. Não creio que eles jamais tenham a mesma sensação de lutar contra o tempo ou de terem de coordenar as atividades com uma passagem abstrata do tempo, porque seus pontos de referência são principalmente as próprias atividades, que, em geral, têm o caráter de lazer. Os acontecimentos seguem uma ordem lógica, mas não são controlados por um sistema abstrato, não havendo pontos de referência autônomos aos quais as atividades devem se conformar com precisão. Os Nuer têm sorte. (EVANS-PRITCHARD, 2007, p. 116)

Os pontos de referência da tribo são a natureza e as atividades realizadas no cotidiano. O nosso é o relógio. Os nuer seriam felizes e teriam sorte porque a vida não lhes exige tanta disciplina, autocontrole e seriedade. A felicidade de quem não conhece o tempo do relógio deve-se ao fato de que nós, que o conhecemos, temos a sensação contínua de estarmos 


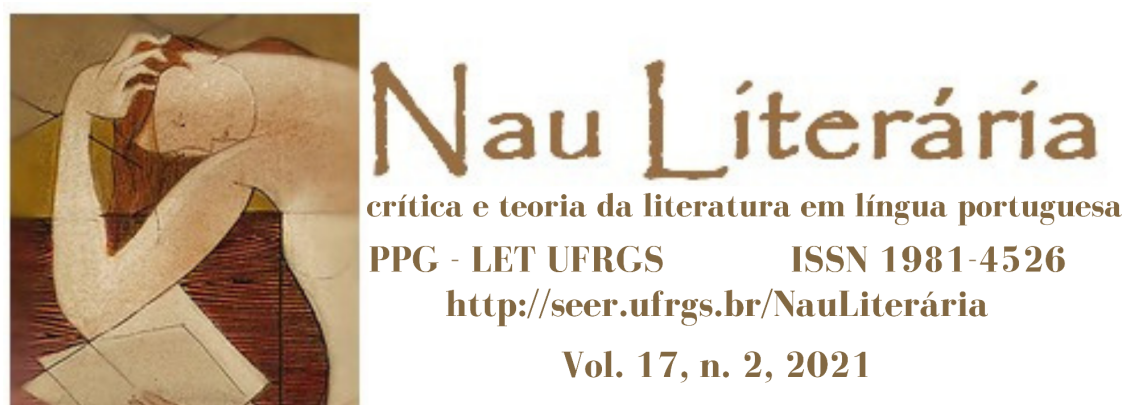

perdendo o tempo. Há uma separação muito clara entre trabalho e lazer nas sociedades modernas. O próprio capitalismo instaura esse movimento de sístole e diástole no controle do tempo burguês.

O movimento de tensão e relaxamento do tempo pode ser percebido nos versos de João Cabral de Melo Neto em "Para mascar com chiclets": "[...] o chiclets ora se contrai ora se dilata,/ e consubstante ao tempo, se rompe,/ interrompe, embora logo se remende,/ e fique a romper-se, a remendar-se,/ sem usura nem fim, do fio de sempre.” (MELO NETO, 2008, p. 263-264). Por que, então, tempo e dinheiro seriam equivalentes? Com as mudanças ocorridas após a Revolução Industrial, o dinheiro ganhou uma dimensão universal, pois ele é capaz de transformar qualquer quantidade em toda qualidade. O dinheiro torna-se, dessa maneira, a unidade que mede todas as coisas, assim como o relógio pelo qual medimos nossa vida e nossas ações de acordo com o tempo disponível.

Segundo Edward Thompson, em Costumes em comum, em uma comunidade como a dos nuer há pouca separação entre trabalho e vida, o que significa que há uma estrutura econômica e administrativa mínima. Contudo, no mundo moderno e industrializado, os empregadores das fábricas devem zelar pela qualidade do tempo de trabalho,

[...] usar o tempo de sua mão-de-obra e cuidar para que não seja desperdiçado; o que predomina não é tarefa, mas o valor do tempo quando reduzido a dinheiro. O tempo é agora moeda: ninguém passa o tempo e sim o gasta. (THOMPSON, 1998, p. 272)

Assim, o tempo transforma-se em dinheiro. Com a instalação da nova disciplina do tempo, as sociedades capitalistas maduras são marcadas “[...] pela administração do tempo e por uma clara demarcação entre 'trabalho' e a 'vida'. [...] Sem a disciplina do tempo, não teríamos as energias persistentes do homem industrial [...].” (THOMPSON, 1998, p. 300).

Em O pai Goriot, Eugène de Rastignac ganha um relógio de presente da sra. de Nucingen:

[Rastignac] Voltou-se para a estufa e percebeu ali a caixinha quadrada, abriu-a e encontrou dentro dela um pedaço de papel que cobria um relógio Bréguet. [...] $\mathrm{Na}$ parte interna, suas armas estavam gravadas no ouro da caixa. Aquela joia, desejada durante tanto tempo, a 


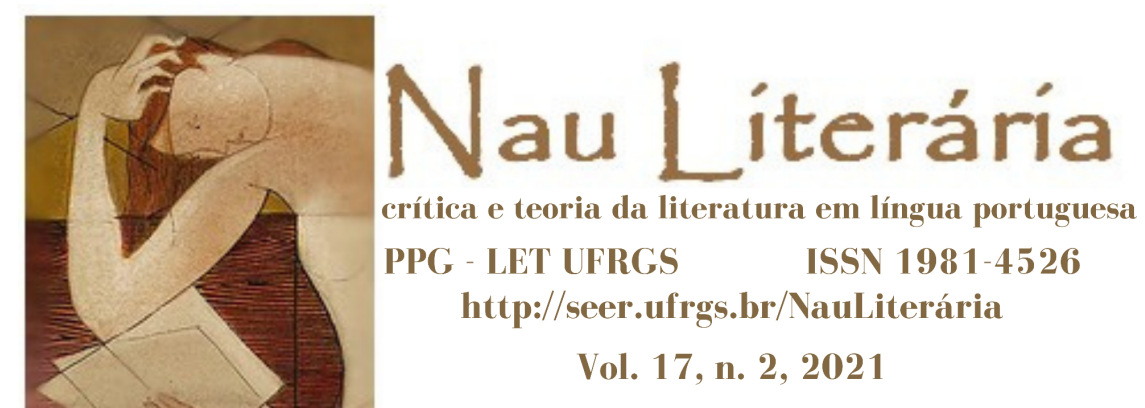

corrente, a chave, o feitio, os desenhos, tudo correspondia a seus desejos. (BALZAC, 2012, p. 209-210, grifo nosso)

O relógio era, ainda no século XIX, um artigo de luxo. Para além dessa importante informação, dois detalhes nos chamam a atenção: o primeiro é que Rastignac precisa de dinheiro para pagar dívidas contraídas devido à doença do pai Goriot. $\mathrm{O}$ único objeto de valor que ele possui é o relógio dado por Delphine. O arrivista não pensa duas vezes e vende o objeto para saldar suas dívidas:

- Olha, vamos precisar de muitas coisas. Onde arranjaremos dinheiro?

Rastignac tirou o relógio.

- Toma, empenha isto. Não quero parar no caminho, para não perder tempo. Estou esperando Cristóvão. Não tenho dinheiro algum e preciso pagar o cocheiro na volta. (BALZAC, 2012, p. 308 , grifo nosso)

O segundo detalhe é que um presente é uma dádiva que não pode ser vendida, pois simboliza afeto e consideração. Então, por que Rastignac vende o presente por motivos aparentemente menores do que a dimensão do gesto de Delphine ao presenteá-lo? Bianchon, seu amigo, é quem empenha o relógio. Eugène não podia fazê-lo para não perder tempo. Essa situação demonstra que o tempo pode ser transformado em dinheiro:

Eugênio voltou rapidamente ao quarto do pai Goriot.

- Bianchon, onde está o dinheiro do relógio?

- Em cima da mesa. Sobraram trezentos e sessenta e poucos francos. Com o dinheiro que me deram, paguei tudo quanto devíamos. O recibo da Casa de Penhor está debaixo do dinheiro. (BALZAC, 2012, p. 312, grifo nosso)

Além de pagar suas dívidas, Rastignac ainda lucra com a venda do relógio. Em momento algum o arrivista se preocupa com o que a sra. de Nucingen vai pensar quando souber que ele vendeu o presente no qual ela mandou gravar as armas da família Rastignac na caixa. Eugène, literalmente, vende o controle do tempo para conseguir dinheiro, mostrando a nova ordem capitalista inserida no mundo balzaquiano. É interessante notar que, para Rastignac, o relógio era um objeto desejado há bastante tempo, talvez por ser um objeto identificado com a alta sociedade. O gesto de vendê-lo sem se preocupar com as possíveis consequências em relação à Delphine antecipa, de certa forma, o desafio no final do romance, 


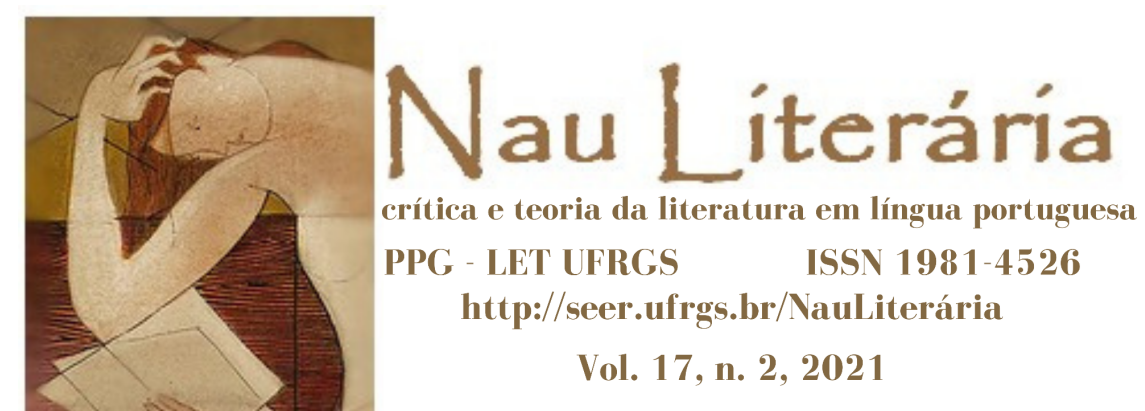

pois ele também não se importa mais com sentimentos alheios e adota a indiferença como forma de vencer a sociedade.

A respeito do tempo do capitalismo, o historiador alemão Reinhart Koselleck argumenta, em Estratos do tempo, que o tempo deixa de ter um caráter essencialmente ligado à natureza, à biologia e à astrologia devido à introdução do modo capitalista de produção e à algumas invenções que, a longo prazo, contribuíram para esse fenômeno, como é o caso do relógio mecânico criado no século XIV. A introdução desse tipo de relógio torna-se fundamental, pois quantificou a duração do dia em vinte e quatro horas idênticas. Segundo Koselleck, toda “[...] a história da medição do tempo pode ser descrita, sob a perspectiva de sua função social [...].” (KOSELLECK, 2014, p. 143).

O relógio mecânico, que foi paulatinamente “[...] descendo da torre do castelo ou da igreja para o paço municipal, invadiu as salas, alojando-se finalmente nos bolsos dos coletes [...]" (KOSELLECK, 2014, p. 144), a partir do século XVI, passou a indicar, além das horas, os minutos e, no século XVII, os segundos: esse “[...] relógio era certamente um indicador, mas também era estimulador do disciplinamento, da racionalização do mundo do trabalho humano e de suas margens de ação.” (KOSELLECK, 2014, p. 144).

Com a nova disciplina do tempo imposta pelo capitalismo, o sujeito passa a ter uma nova identidade associada aos novos valores emergentes da sociedade em processo de modernização. A Revolução Francesa, que ocorreu no entremeio da Revolução Industrial, promove um tratamento mais horizontal na sociedade hierárquica do fim do século XVIII e do início do século XIX.

O sujeito moderno está em uma eterna luta contra os prazos exigidos pela sociedade capitalista. O tempo apresenta-se como uma figura ambivalente por excelência, uma entidade cujo rosto está sempre mudando: ora ele mostra sua face positiva ao promover o controle, a organização e a regularidade da vida, o que proporciona o ganho de capital, ora ele demonstra sua face negativa ao se transformar no agente da corrosão da energia vital do sujeito, convertendo-se no culpado pela morte de sua felicidade, como afirma W. H. Auden no poema 


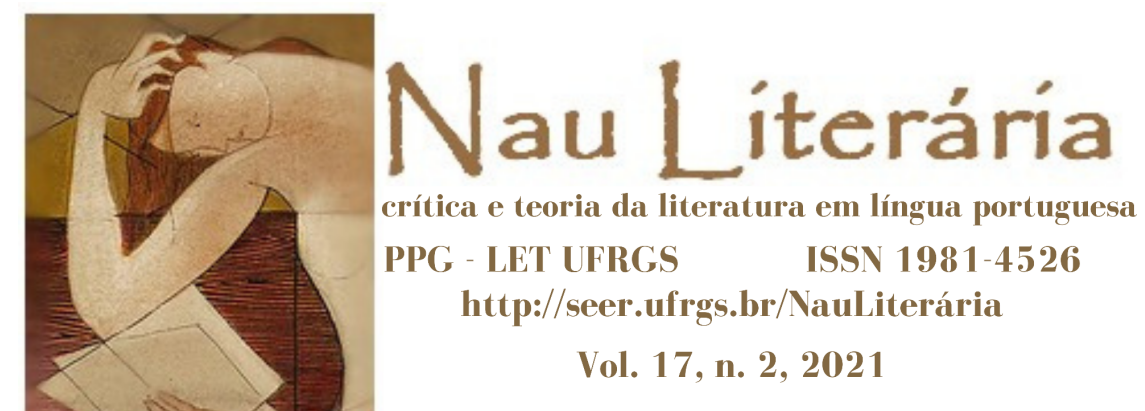

"História de detetive": "Mas o tempo é o culpado sempre. Alguém tem de pagar/ Pela morte da felicidade, a nossa própria felicidade.”(AUDEN, 2013, p. 53).

\section{3 "Democracia das sensações": a herança da Revolução Francesa}

Rancière (2017) discute, em $O$ fio perdido, a descoberta, por meio da ruptura provocada pela Revolução Francesa, de uma capacidade inédita do povo de vivenciar formas de experiência que lhes eram recusadas até esse período. Associa-se, a essa descoberta, o rompimento da hierarquia da ação, do modelo aristotélico, que preconizava que uma história deve ter, obrigatoriamente, começo, meio e fim. Rancière (2017) argumenta que a ficção moderna não possui um fim. O final em aberto do romance e o rompimento da hierarquia da ação demonstram que a realidade é contingente, ou seja, ela poderia também ser de outra forma.

O que legitima a mobilidade social são as diversas instituições nas quais o sujeito se insere, ou é inserido, e que facilitariam a vivência dessas experiências. A Revolução Francesa quebra os padrões vigentes da sociedade em que cada um deve permanecer em seu estamento social - o que não quer dizer que a mobilidade social não existia: ela apenas não acontecia com tanta frequência, não era legitimada simbolicamente e não era desejável. Como exemplo disso, há as comédias de Molière, escritas no século XVII, nas quais o autor descreve que o maior defeito que alguém poderia ter naquele tempo é não saber o lugar social ao qual pertence: os novos ricos não sabem, por exemplo, se portar à mesa e são motivo de riso. Nas comédias do século XVII vê-se a aplicação do conceito aristotélico de que a comédia trata dos homens piores do que são.

Segundo Graeber (2016), Immanuel Wallerstein afirmava que a Revolução Francesa havia contribuído com três aspectos na política, a saber: a mobilidade social passa a ter um caráter positivo, a responsabilidade pela mudança é do governo, que define as condições e as regras em que ela deve acontecer, partindo do princípio de que haverá uma competição justa 


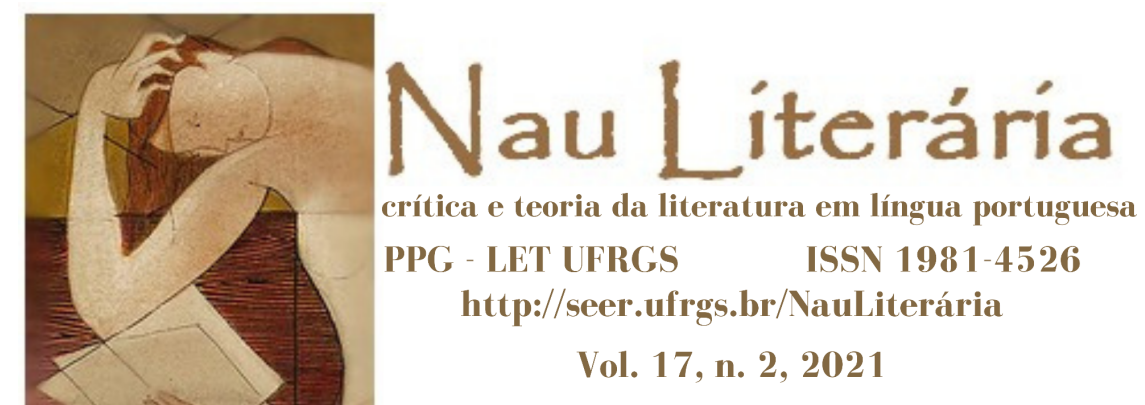

entre os indivíduos e este atuaria, portanto, como uma instância reguladora da competição, e a legitimidade do governo está nas mãos da sociedade:

\begin{abstract}
Immanuel Wallerstein costuma dizer que a Revolução Francesa introduziu na política diversas ideias extremamente novas - ideias que, cinquenta anos antes da revolução, a maioria dos europeus instruídos teria descartado como insanas, mas que, cinquenta anos depois, praticamente todos sentiam que tinham de ao menos fingir que acreditavam nelas. A primeira é que a mudança social é inevitável e desejável: que a direção natural da história é a da melhora gradual da civilização. A segunda é que o governo é o agente ideal para efetuar essa mudança. A terceira é que a legitimidade do governo é dada por um ente chamado "povo". (GRAEBER, 2016, p. 451)
\end{abstract}

Cinquenta anos depois da revolução, segundo Wallerstein, citado por Graeber (2016, p. 451), todos deveriam pelo menos fingir que acreditavam nessas mudanças. Isso quer dizer que ainda que não se acredite nelas, não se pode afirmar que se é a favor da desigualdade, seja ela de qualquer espécie. Em nossa sociedade, sobretudo no século XXI, isso torna-se muito claro. Todos os discursos, mesmo que ideologicamente diferentes, preconizam essa ideia, embora muitas vezes acreditem que a desigualdade é necessária e vantajosa. A mobilidade social é desejável e legitimada em nossa sociedade, mas é um horizonte distante porque ainda assim não acontece com frequência.

O horizonte dos jovens nos romances de Balzac, por exemplo, é Napoleão Bonaparte. $\mathrm{O}$ ato de coroar a si mesmo como imperador da França demonstra que o indivíduo constrói a si próprio: é a figura por excelência do self-made man e, mais ainda, do arrivista, bem como do empreendedor. Todos os arrivistas balzaquianos têm um "busto de Napoleão" em seus quartos localizados numa pensão barata e o lema "carreira aberta ao talento" em suas mentes. Mas Napoleão é um caso à parte, porque o que acontece uma vez, não necessariamente acontecerá sempre. Não são todos os que podem retirar a coroa das mãos do papa e colocá-la sobre suas cabeças.

Do mesmo modo, no Brasil, por exemplo, podemos perceber um certo viés cômico desse horizonte. Somos um país obcecado com o empreendedorismo, uma das palavras mais repetidas nos últimos anos, recebemos diariamente incentivos, anúncios de desburocratização 


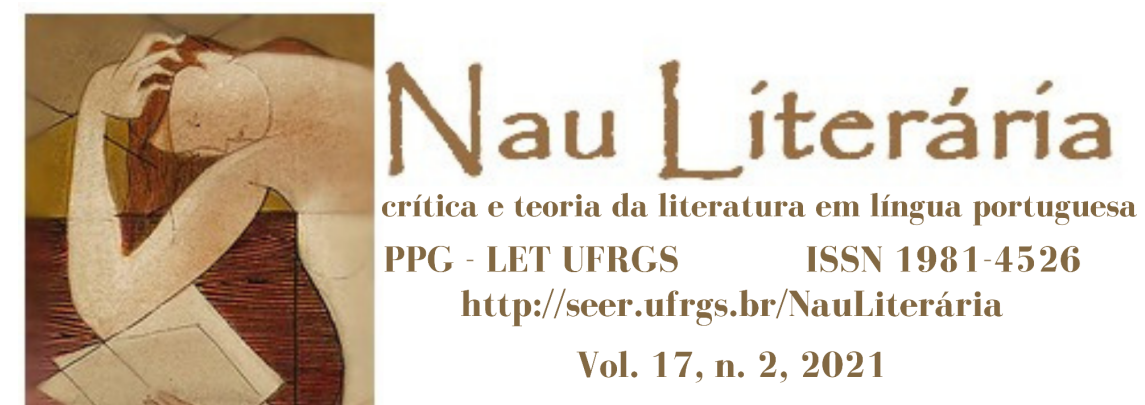

das leis e propagandas, para que qualquer brasileiro invista em um negócio próprio sem sair de casa, mas somos um dos países mais desiguais do mundo. Dessa forma, o mito napoleônico não será possível de acontecer com frequência também aqui, no maior país da América do Sul. Ainda assim, o incentivo maçante acontece e a ideia é cada vez mais difundida, o que caracterizaria o viés cômico ao qual nos referimos.

Pressupõe-se, com a Revolução Francesa, que ocorra um tratamento mais horizontal entre as pessoas no sentido de que se instala uma crise de autoridade no mundo moderno. Não há mais a figura do Zeus que tudo vê e julga, bem como a figura do rei absolutista. O que há são diversas vozes no mundo moderno no lugar de uma única voz, pois este “[...] não é apenas o mundo da circulação incessante das grandes cidades. É, sobretudo, um mundo sem um apoio estável, sem circunferência definível, nem identidades bem estabelecidas." (RANCIÈRE, 2017, p. 115). O que passa a vigorar é um sentimento de perplexidade dos jovens em formação, pois, em meio a tantas vozes, eles não podem mais ser aconselhados e fica cada vez mais difícil escolher um guia confiável.

$\mathrm{Na}$ nova ordem estética instaurada pela Revolução Francesa, os detalhes compreendidos dentro do romance - ou os enchimentos, de acordo com a nomenclatura eleita por Moretti (2014) - tornam, segundo o crítico Armand de Portmartin, citado por Rancière (2017, p. 73-74), referindo-se a Madame Bovary, todos os episódios romanescos são igualmente essenciais e acessórios, pois

[...] essa nova aptidão dos anônimos de viver qualquer vida que permitiu à ficção moderna romper com a lógica hierárquica da ação e encontrar sua matéria em qualquer acontecimento insignificante. (RANCIÈRE, 2017, p. 73-74)

Portmartin acredita que essa igualdade seja um "defeito" do romance de Flaubert. Contudo, Rancière vê na igualdade uma qualidade dos romances produzidos no final do século XIX e no início do século XX. O que seria um acontecimento desnecessário? Não teria esse momento grande importância para a narrativa? No caso do romance Madame Bovary, uma cena aparentemente banal torna-se central na narrativa. A cena em questão é a descrição 


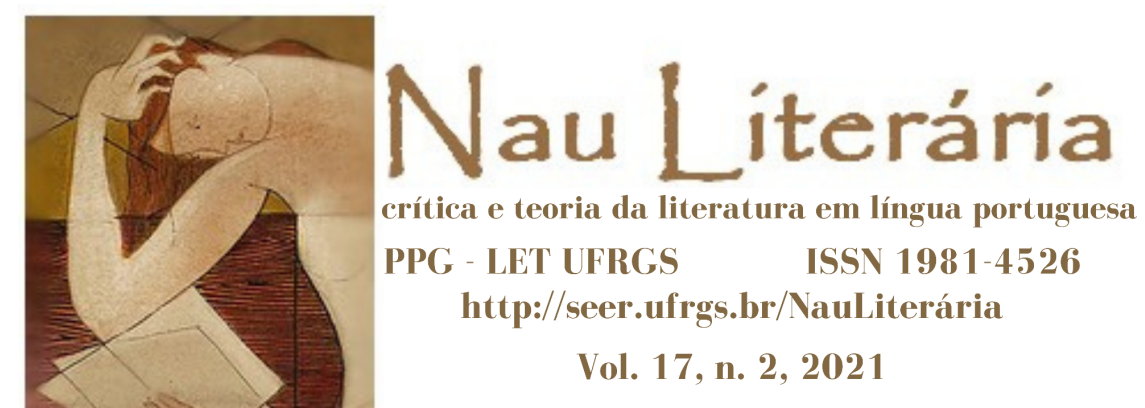

do jantar do casal Emma e Charles Bovary, na qual o principal é o desespero de Emma e não a cena do jantar em si.

Emma não suportava mais a hora do jantar. Toda a descrição das sensações da personagem contribui para atestar seu enfado e seu nojo em relação à comida, à casa e ao marido. A vagareza de Charles ao comer e a diversão de Emma ao riscar a mesa com uma faca denotam o cansaço da protagonista do romance. $\mathrm{O}$ ato de riscar a mesa demonstra que não havia uma toalha, detalhe que incomoda profundamente a personagem. A ausência da toalha, a percepção da simplicidade da casa e a comida habitual fazem com que Emma conclua que sua vida é comum demais e o olhar dela para o marido mostra ao leitor que Charles é o causador desse problema.

Essa cena aparentemente banal culmina depois na narração do descuido de Emma em relação a si mesma - ela adoece - e à casa. Dessa forma, a cena do jantar seria um enchimento que revela o momento decisivo que, por sua vez, é o desespero de Emma e as consequências de sua constatação da vida que leva. Esse acontecimento é o que possibilita o andamento do restante da narrativa. Além disso, Emma Bovary é um exemplo da dissolução dos papéis demarcados na ficção moderna, pois ela desejava vivenciar as experiências narradas nos romances que lia, a fim de acabar com a repetição de seu cotidiano, mas que não eram destinadas às moças de sua classe social.

A "democracia na literatura" promove uma igualdade de todos os seres, de todas as coisas e de todas as situações. Se são detalhes insignificantes é porque estão ligados a pessoas cujas vidas são insignificantes, como é o caso do casal Bovary. Isso quer dizer que há excesso de pessoas no romance que, portanto, não merecem ser distinguidas pela ficção - por esse motivo, essa cena do romance de Flaubert é tão expressiva dessa mudança, que é personificada em Emma. Corre-se o risco, então, de o romance ter como sua matéria o nada, o insignificante, atacando, portanto, o princípio da verossimilhança aristotélica que vigorava até o momento. 


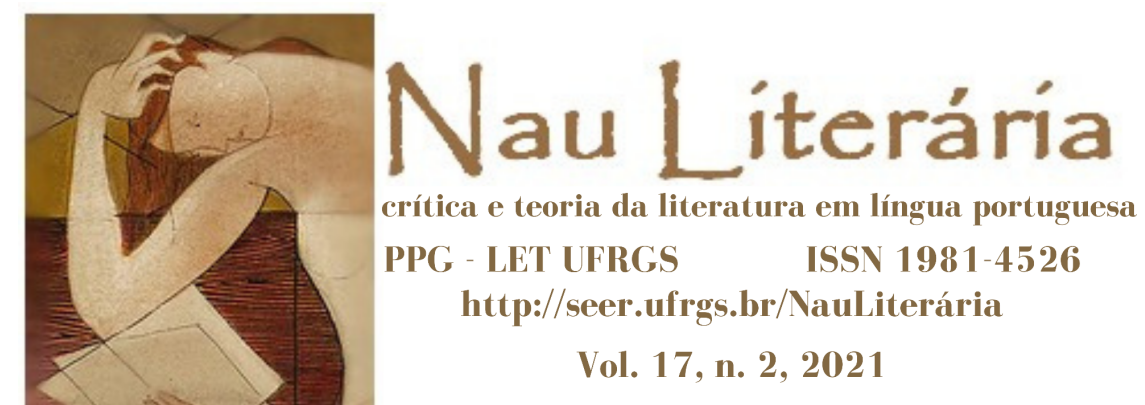

Contudo, muitas vezes, o que aparentemente é o nada, pode se converter em tudo, como vimos em Madame Bovary e como veremos em São Bernardo. A cena do jantar revela, por meio da falta da toalha e do ranger dos talheres, que a junção dos elementos aparentemente insignificantes promove o caos, a narrativa passa a tratar de coisas que estão no plano da percepção do sujeito e esses enchimentos mostram que algo está sendo corroído de forma invisível para as personagens, como veremos também em São Bernardo. Emma revela a crise de autoridade do mundo moderno, visto que não havia nenhuma figura que pudesse julgá-la, a fim de frear seu desejo.

O problema, para Rancière, não é que

[...] os seres comuns atravanquem o espaço antes destinado ao desenvolvimento dos sentimentos refinados com seus problemas prosaicos. Acontece que suas novas paixões vêm embaralhar a própria divisão entre as almas de ouro destinadas aos sentimentos refinados e as almas de ferro destinadas às atividades prosaicas. (RANCIÈRE, 2017, p. 24)

O equilíbrio das partes do romance em relação ao todo devia-se à divisão entre a elite e o povo, que sempre teve seu lugar na ficção, mas numa posição subalterna ou num gênero inferior que permitia sua presença em lugar de maior destaque, como é o caso da comédia. A mudança de lugar do povo na ficção moderna quebra justamente com essa fixidez de papéis. Dessa maneira, não é mais possível diferenciar aqueles que pensam, agem, sonham e sentem, e aqueles que estão presos na repetição do cotidiano.

O grande problema descrito pelo autor é a vastidão do mundo moderno. O modelo aristotélico necessitava de um mundo finito, de um cosmo fechado. O mundo, tornando-se um universo infinito, no qual o herói do romance, ao olhar para o céu, encontra um abismo no lugar da cúpula dos deuses do Olimpo, torna-se grande demais para que a verossimilhança aristotélica sobreviva, ainda que ela não tenha desaparecido por completo.

O recurso linguístico usado por Flaubert para mostrar a vida tediosa de Emma Bovary é o uso dos verbos no passado imperfeito. Esse tempo verbal é usado para demonstrar repetição e continuidade. Em Balzac, por exemplo, o uso do imperfeito é muito inferior ao uso do passado perfeito, o que denota a quebra da repetição. O uso do passado imperfeito é 


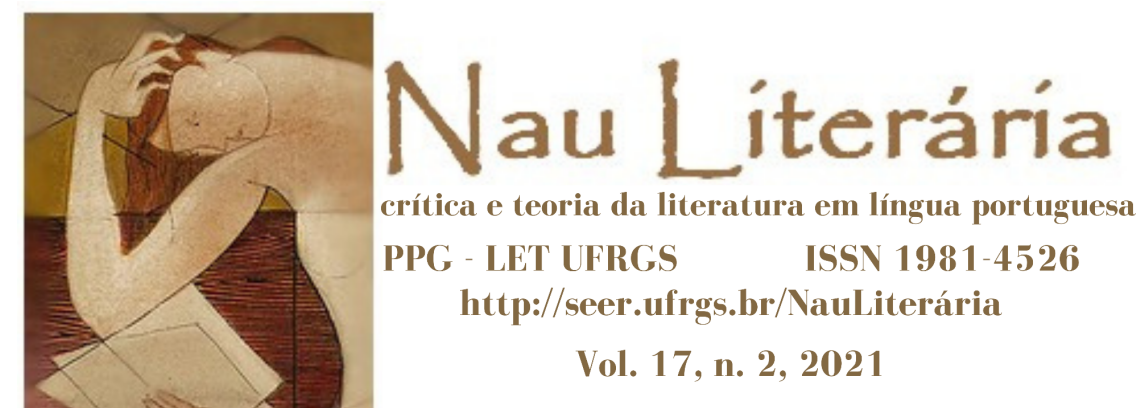

também uma forma de indicar os enchimentos no romance, além de mostrar a extrema regularidade da vida burguesa e a absoluta falta de perspectiva da personagem. $\mathrm{O}$ uso desse tempo verbal mostra a prisão em que a personagem se encontra ao tornar-se acessória da cena na qual ela é protagonista.

\section{A identidade fragmentada do sujeito: posicionar-se ou ser posicionado?}

Stuart Hall, na obra $A$ identidade cultural na pós-modernidade, define a identidade na pós-modernidade a partir de um caso específico: a indicação, em 1991, do juiz Clarence Thomas, pelo então presidente George H. W. Bush, à Suprema Corte americana. Durante o período de discussões no Senado em torno da indicação, o juiz foi acusado de assédio sexual por sua ex-colega, Anita Hill, o que suscitou críticas severas a ele no movimento negro. O que está em jogo nesse caso não é a inocência ou a culpa do juiz: a discussão mais importante que Hall propõe é entender o "jogo das identidades” e suas consequências políticas.

Acreditamos que, mesmo definindo a identidade por meio de um caso específico, podemos usar a definição do autor para nossos objetos de análise, pois a definição de identidade é baseada na forma como somos interpelados nos sistemas culturais que nos rodeiam, ou seja, somos construídos enquanto sujeitos por intermédio das instituições nas quais nos inserimos ou somos inseridos. As instituições surgem com o mundo em processo de modernização. Balzac e sua obra se inserem justamente nesse período. Já Graciliano Ramos situa-se num tempo em que essas instituições já estão estabelecidas e estão relativamente solidificadas.

Hall defende que não há uma identidade permanente. O que há é um conflito interno entre as múltiplas identidades existentes no sujeito. Para o autor, a identidade formada, fixa, unificada não passa de uma fantasia. A identidade torna-se, assim,

[...] uma "celebração móvel": formada e transformada continuamente em relação às formas pelas quais somos representados ou interpelados nos sistemas culturais que nos rodeiam [...]. É definida historicamente, e não biologicamente. O sujeito assume identidades diferentes em diferentes momentos, identidades que não são unificadas ao redor de um "eu" coerente. Dentro 


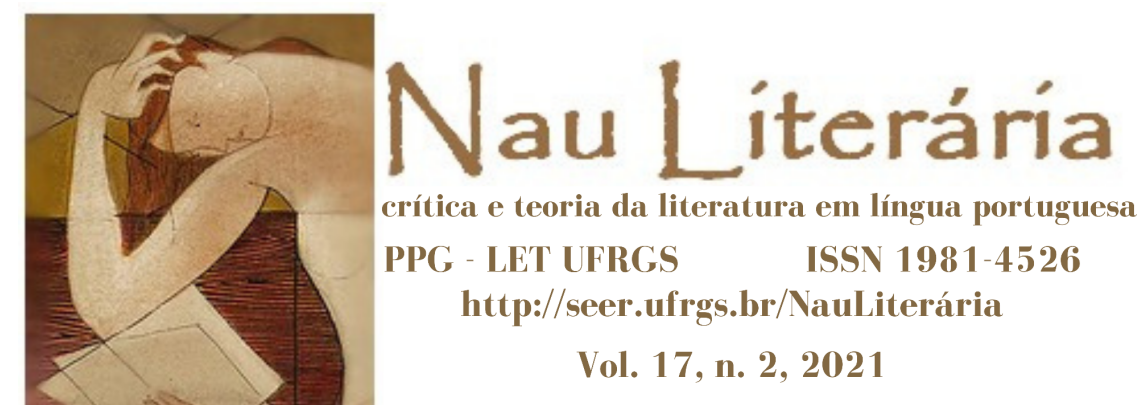

de nós há identidades contraditórias, empurrando em diferentes direções, de tal modo que nossas identificações estão continuamente deslocadas. (HALL, 2006, p. 13, grifo nosso)

Como podemos notar, a identidade seria formada pelas maneiras nas quais nos posicionamos e/ou somos posicionados nas diversas instituições que nos rodeiam. O conceito proposto pelo autor nos ajuda a formular a hipótese de que a identidade nada mais seria do que um efeito narrativo, ou seja, o efeito produzido pela adequação das identidades do sujeito nos espaços que ele frequenta. Identidade e narrativa são, portanto, indissociáveis. Há um reconhecimento de que a narrativa nunca conhecerá sua forma final, como afirma Rancière, e, se essa definição se assemelha à definição de identidade, então, ela não poderá ser definida de uma vez por todas.

Podemos considerar que a obra de Balzac é um ponto de inflexão da reelaboração da definição de identidade, pois haveria um entendimento da personagem como a cristalização das diversas circunstâncias nas quais ela foi lançada. Há, na obra balzaquiana, uma suspensão do juízo, visto que não tem uma definição clara e precisa do caráter da personagem. $\mathrm{O}$ que Balzac apresenta são os prós e os contras, mas a síntese não é possível de ser feita porque não existe mais um código que possa definir o caráter da personagem do romance, daí a suspensão do juízo praticada pelo narrador balzaquiano. A crise instaurada pela modernidade em ascensão na época em que Balzac escreve perpassa essa dificuldade em dar a palavra final a respeito de um caráter.

A personagem Goriot, por exemplo, tem sua identidade marcada pela Revolução Francesa: “João Joaquim Goriot era, antes da Revolução, um simples operário numa fábrica de massas, hábil, econômico e bastante arrojado para comprar o estabelecimento do patrão, que o acaso tornou vítima da primeira sublevação em 1789.” (BALZAC, 2012, p. 116, grifo nosso). Após a Revolução Francesa, Goriot enriqueceu vendendo trigo a um preço bem mais elevado do que o valor de mercado. O pai Goriot nos é apresentado como um velho constantemente explorado pelas filhas, o que nos faz sentir, como leitores, certa empatia por ele. Aliás, desde as primeiras páginas somos advertidos, pelo narrador, de que os infortúnios do pai Goriot nos farão conhecer o que há de mais cruel no coração humano. Contudo, há 


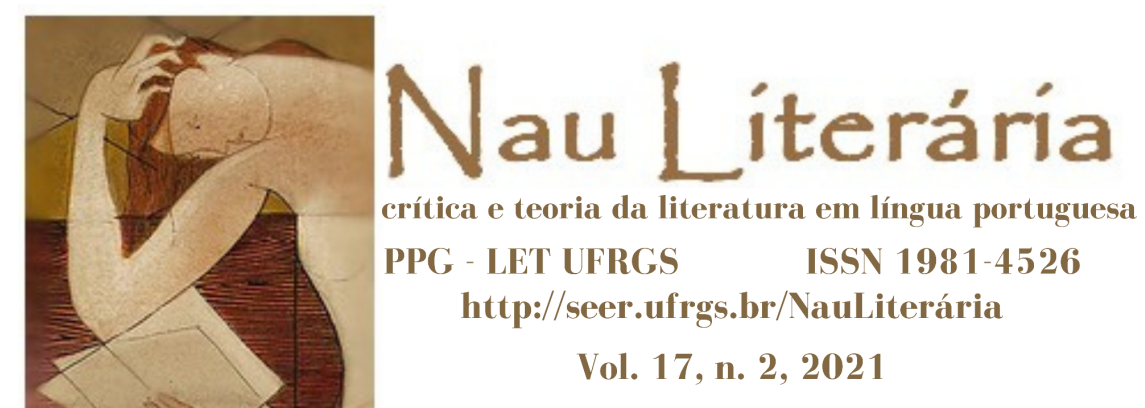

diversas passagens do romance em que Goriot planeja pequenos "golpes" para ajudar as filhas, deseja avidamente matar seus genros e afirma que seria capaz de tudo por Anastasie e Delphine. Vemos também que a forma pela qual Goriot constituiu sua fortuna não foi honesta. Então, nós, leitores, não podemos julgar Goriot, visto que não temos mais aparatos para fazê-lo.

A definição da identidade pela história evidencia o deslocamento da ideia, que prevalecia antes da Revolução Francesa, de que o sujeito se definia a partir de sua família ou do lugar em que nasceu. Em Balzac, ele se define não apenas pelos marcos históricos, mas principalmente por suas ações, como é o caso de Goriot. Dessa maneira, assumindo as responsabilidades de suas ações, o sujeito torna-se, a princípio, seu próprio dono, serve a si mesmo e não mais a terceiros, se equilibrando e usando, conforme sua necessidade, os diversos papéis dos quais dispõe nas várias instituições presentes no mundo moderno. Na verdade, o sujeito acredita que sempre detém o controle de suas ações, mas, por vezes, ele está sendo controlado pelas circunstâncias externas, como, por exemplo, questões econômicas, políticas e sociais, conforme veremos no caso de Paulo Honório em São Bernardo.

A identidade tem, portanto, “[...] sempre algo 'imaginário' ou fantasiado sobre sua unidade. Ela permanece sempre incompleta, está sempre 'em processo', sempre 'sendo formada'." (HALL, 2006, p. 38). Sendo o sujeito um ser em constante movimento, a sociedade na qual ele se encontra também não é fixa. Isso provoca uma falta de ponto de apoio na sociedade moderna. O sujeito, portanto, está só, diferentemente do herói homérico que possuía o apoio incondicional dos deuses e que possuía também um juiz para resolver seus conflitos. Com a modernidade, o sujeito tornou-se o efeito provisório dos modos de interagir com as instituições, pois ele foi inserido e definido nas maquinarias burocráticas e administrativas do Estado, que sustentam a sociedade industrializada. Dessa forma, quanto mais a vida social se torna mediada pelo mercado da globalização e pelo dinheiro, mais as 


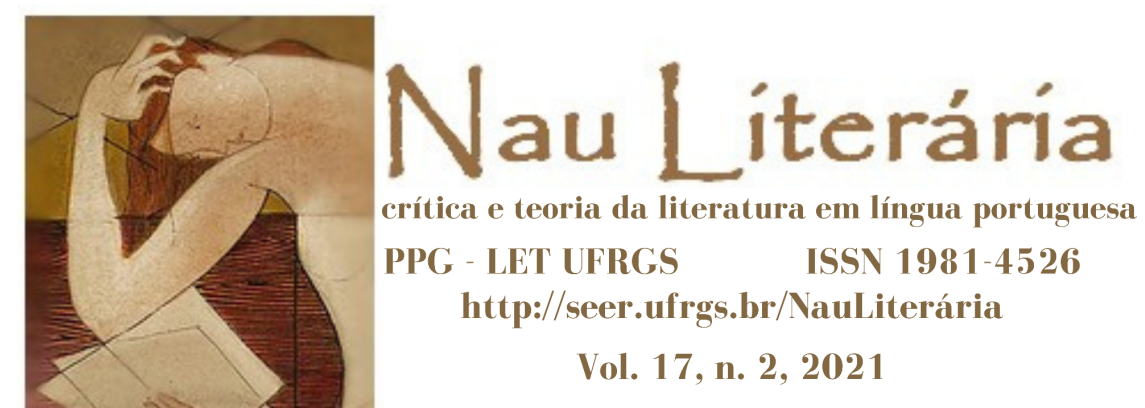

identidades se tornam desvinculadas e fragmentadas. A fragmentação do sujeito é tratada nos dois romances que nos propusemos a analisar, como veremos adiante.

\section{Rastignac e Paulo Honório: do "projétil de artilharia" ao "dínamo emperrado"}

O romance São Bernardo, de Graciliano Ramos, parece retomar alguns tópicos tratados nos romances do século XIX, e que são explorados por Balzac, ao mesmo tempo em que se insere nos romances produzidos no século XX. A figura do self-made man, típica do século XIX, volta na obra de Graciliano Ramos, por intermédio da figura de Paulo Honório, a fim de demonstrar a crise do homem que faz a si mesmo, por meio da corrosão provocada pelo tempo e pelos pequenos acontecimentos aparentemente insignificantes que provocam o colapso na vida do narrador. O pio da coruja e o tique-taque do relógio incomodam tanto Paulo Honório quanto a mesa sem toalha e o ranger dos talheres incomodam a sra. Bovary.

O narrador de São Bernardo era um sujeito sem posses que teve que fazer muitas coisas, das quais não tem noção se são boas ou ruins, para sobreviver. Assim como em $O$ pai Goriot e em Madame Bovary, não há nenhuma palavra final a respeito de seus atos. $\mathrm{O}$ movimento de Paulo Honório no livro é a ascensão do nada para o ganho de algo (a fazenda S. Bernardo) e, a partir do capítulo 13 do romance (quando o narrador afirma que o capítulo vai se bifurcar por causa de Madalena), faz-se o movimento inverso: o ganho é reduzido a nada, pois tudo o que ele conquistou perde o sentido a partir da morte de Madalena.

A imagem usada para explicar essas transformações de estágios é o dínamo emperrado. O episódio acontece 10 capítulos depois da bifurcação, mas é desse episódio em diante que o cansaço de Paulo Honório torna-se ainda mais evidente. O dínamo que emperra é, digamos, o prenúncio do destino de Paulo Honório e do relógio parado. De igual modo, o carro da civilização que atropela as pessoas na rua, que aparece nas primeiras páginas de $O$ pai Goriot, de Balzac, é a antecipação do que será o jovem Eugène de Rastignac.

Uma aproximação interessante entre os romances é a semelhança entre o conceito de "semana fatal" e o termo "caiporismo", que aparece em São Bernardo, cujo significado é azar, 


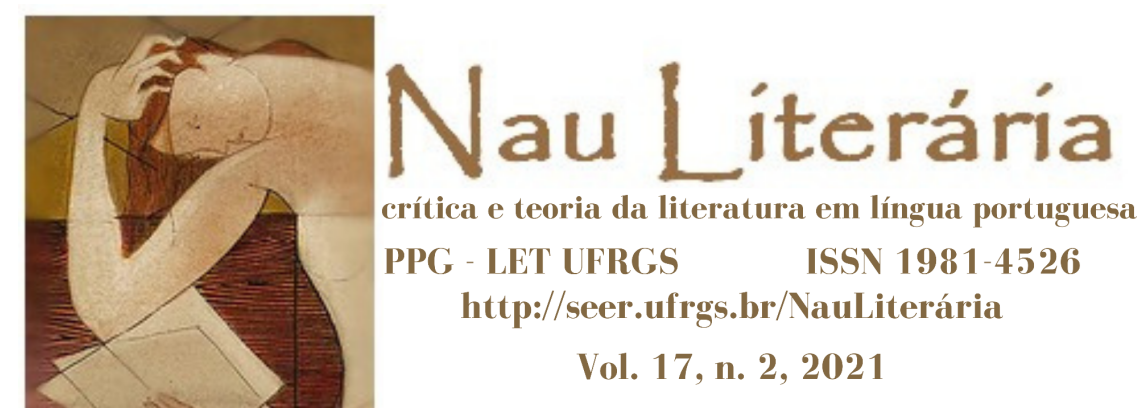

má sorte. O caipora é uma figura do folclore brasileiro, que aparece em definições de dicionários da língua portuguesa, bem como em outras obras literárias, como em alguns contos e romances de Machado de Assis e em Grande Sertão: Veredas, de Guimarães Rosa. O caipora é aquele que tenta de tudo e não consegue êxito: “Ainda por cima os bancos me fecharam as portas. Não sei porque, mas fecharam. E olhem que nunca atrasei pagamentos. Enfim uma penca de caiporismos." (RAMOS, 1990, p. 178, grifo nosso). O penúltimo capítulo do romance inicia-se com Paulo Honório afirmando que havia começado o ano com o pé esquerdo e que uma infelicidade não vem sozinha. O empreendedor voraz, portanto, torna-se um caipora.

Todos os seus investimentos passam a dar errado após a morte de Madalena. A culpa recai sobre a crise ou o preço alto do dólar, mas nunca sobre si próprio. Cabe ressaltar que o romance de Graciliano Ramos foi escrito pouco depois da crise de 1929 e ainda se sentia seus efeitos no Brasil e no mundo. Uma hipótese que poderia ser formulada para pensar o motivo da recusa dos bancos seria o fato de que Paulo Honório tenha percebido que ele não é tão agente quanto pensava e que pode sofrer consequências de algo maior do que ele, como seria o caso de uma crise econômica. Paulo Honório poderia, por meio dessa passagem, reconhecer que não é dono de seu destino e que não tem mais sentido querer conquistar tudo.

No plano linguístico do texto, vemos que o uso de verbos no futuro do pretérito, das parataxes e das conjunções condicionais podem demonstrar como o agir vai cedendo lugar ao ser agido, ou seja, como a atividade vai, progressivamente, se transformando em passividade, como, por exemplo, no trecho a seguir:

Está visto que, cessando esta crise, a propriedade se poderia reconstruir e voltar a ser o que era. A gente do eito se esfalfaria de sol a sol, alimentada com farinha de mandioca e barbatanas de bacalhau; caminhões rodariam novamente, conduzindo mercadorias para a estrada de ferro; a fazenda se encheria outra vez de movimento e rumor.

Nesse movimento e nesse rumor haveria muito choro e haveria muita praga. As criancinhas, nos casebres úmidos e frios, inchariam roídas pela verminose. E Madalena não estaria aqui para mandar-lhes remédio e leite. Os homens e as mulheres seriam animais tristes. (RAMOS, 1990 , p. 181, grifos nossos) 


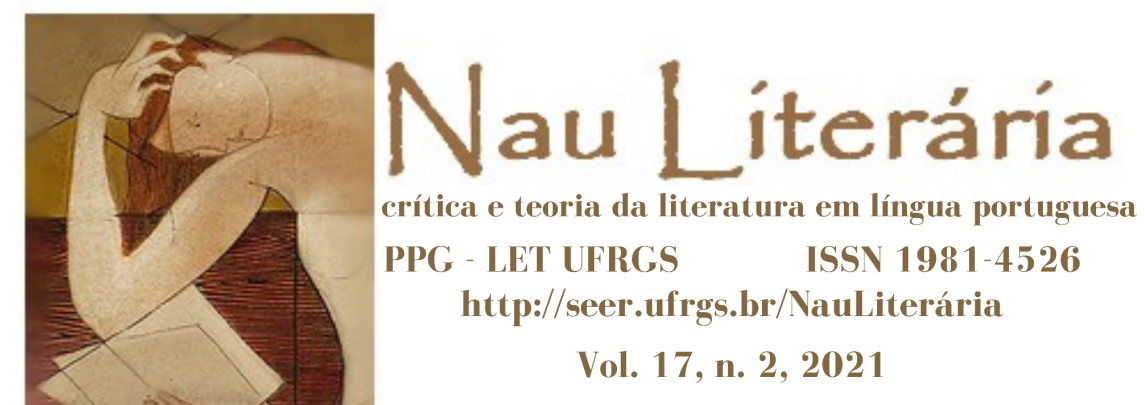

Nota-se que quase todos os verbos desse trecho estão conjugados no futuro do pretérito e há o uso da parataxe. Na primeira frase do trecho, há uma informação interessante, além do uso da conjunção condicional "se": se a crise passar, a fazenda iria se reconstruir sozinha e não Paulo Honório que iria reconstruí-la. Isso denota a passividade tomando o lugar da ação.

A "semana fatal", descrita por Balzac, é a condensação de eventos que dá origem à catástrofe na vida da personagem, no caso na vida de Lucien de Rubempré, em Ilusões perdidas, que pode também pensar que é uma pessoa de má sorte, mas o azar é apenas um componente imaginário para justificar a condensação das migalhas que formam a catástrofe. Balzac, então, nos mostra que os elementos da ruína já estavam presentes, em pequenos fatos, ao longo do romance:

\footnotetext{
$\mathrm{Na}$ vida dos ambiciosos e de todos quantos não podem triunfar senão com a ajuda dos homens e das coisas, segundo um plano de ação mais ou menos bem estabelecido, observado e mantido, há um momento cruel em que não sei que poder os submete a rudes provas: tudo falha ao mesmo tempo, por todos os lados os fios se rompem ou se emaranham, a desgraça surge de todos os cantos. [...] Todo homem, a menos que tenha nascido rico, enfrenta assim o que é preciso chamar a sua semana fatal. (BALZAC, 2013, p. 535-536, grifo nosso)
}

A “semana fatal” ocorre não só com aqueles que são ajudados por homens ou coisas receber ajuda é característica da condição dos arrivistas, como Lucien ou Rastignac, por exemplo, e é importante dizer que há diferenças entre a forma como os dois utilizam essa ajuda -, como também com os ambiciosos. Paulo Honório orgulha-se de ter erguido sua fortuna sozinho, apesar de ser um arrivista, e é um ambicioso. Quando a condensação de fatos se une e produz a catástrofe, tudo falha ao mesmo tempo, a ruína está em toda parte. $\mathrm{O}$ conceito de Balzac aproxima-se muito do termo "caiporismo". É interessante notar que em São Bernardo trata-se de uma "penca de caiporismos", o que denota o efeito ainda mais catastrófico na vida de Paulo Honório.

Uma diferença fundamental entre as personagens de O pai Goriot e de São Bernardo refere-se à formação da identidade de ambas. Enquanto Balzac expõe a formação de um jovem, Graciliano Ramos mostra um homem de cinquenta anos com sua identidade 


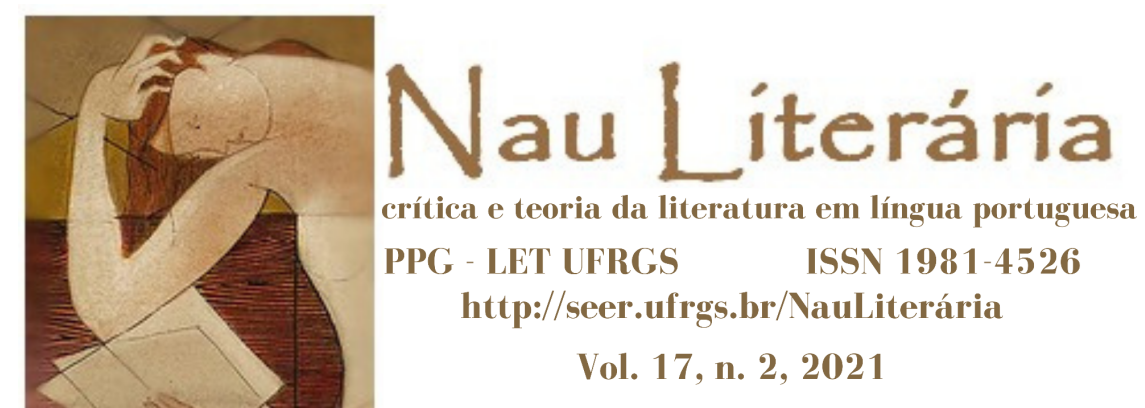

supostamente formada. Como veremos adiante, Paulo Honório, sempre quando tenta dizer quem ele é, acaba por demonstrar sua incapacidade de definir sua própria identidade.

Rastignac é aconselhado por inúmeras pessoas e não ouve ninguém especificamente: ele escolhe os conselhos importantes e usa-os de acordo com a necessidade. Sua identidade em formação mostra que a cacofonia produzida pelos diversos conselhos produz também a fragmentação da identidade de Rastignac. Assim como Paulo Honório, em São Bernardo, ele está por sua própria conta. Não há um mediador de conflitos e nem uma única voz que lhe diga o caminho certo a seguir para conquistar a sociedade parisiense, o que produz nele um estado de perplexidade.

Já Paulo Honório, todas as vezes em que tenta definir sua identidade, acaba sempre mostrando a discrepância entre as diversas tentativas de definição de si próprio, como no trecho a seguir, que se encontra nas primeiras páginas do romance:

O meu fito na vida foi apossar-me das terras de S. Bernardo, construir esta casa, plantar algodão, plantar mamona, levantar a serraria e o descaroçador, introduzir nestas brenhas a pomicultura e a avicultura, adquirir um rebanho bovino regular. (RAMOS, 1990, p. 11, grifo nosso)

A divergência deste trecho ocorre no último capítulo do livro:

O que estou é velho. Cinqüenta anos pelo S. Pedro. Cinqüenta anos perdidos, cinqüenta anos gastos sem objetivo, a maltratar-me e a maltratar os outros. O resultado é que endureci, calejei, e não é um arranhão que penetra nesta casca espessa e vem ferir cá dentro a sensibilidade embotada.

Cinqüenta anos! Quantas horas inúteis! Consumir-se uma pessoa a vida inteira sem saber para quê! (RAMOS, 1990, p. 181, grifos nossos)

As tentativas de definição que Paulo Honório faz ao longo do romance demonstram, não apenas a eterna movimentação e fragmentação de sua identidade, mas também sua incapacidade de apropriação da narrativa de sua vida. Ele, cujo "fito na vida" era possuir a fazenda São Bernardo, não considera mais esse o seu objetivo de vida. Aliás, até mesmo a posse da fazenda já não é mais significativa. A inutilidade das horas gastas com trabalho e 


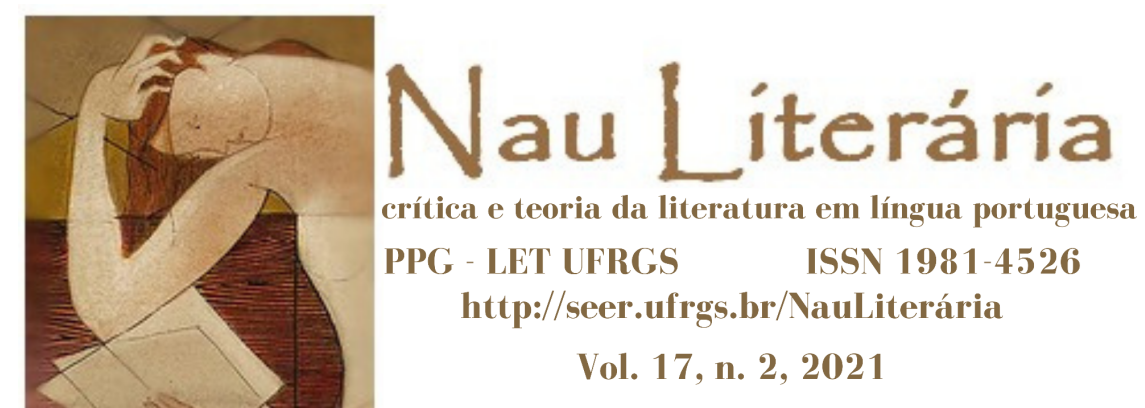

esforço reforça a tese de que o entusiasmo de Paulo Honório se esfriou devido à ação do tempo.

Diferentemente de Rastignac, que possui uma pluralidade de vozes ao seu redor, Paulo Honório possui apenas a voz de Madalena que, depois de sua morte, torna-se um fantasma que o assombra. Paulo Honório não aceita conselhos. Madalena tenta diversas vezes aconselhá-lo, mas ele nunca a ouve num primeiro momento. Os conselhos, as ideias ou as tentativas de Madalena para provocar a reflexão do marido são internalizados por Paulo Honório num segundo momento, como, por exemplo, na cena em que Madalena explica a Paulo Honório o trabalho árduo que D. Glória teve para educá-la:

Madalena acompanhou-me e em caminho falou desta forma:

- Você, pelo que me disse, principiou a vida muito pobre.

- Sei lá como principiei! Quando dei por mim, já era guia de cego. Depois vendi as cocadas da velha Margarida. Já lhe contei.

- Já. Lutou muito. Mas acredite que d. Glória tem desenvolvido mais atividade que você.

- Estou esperando. Que ela fez?

- Tomou conta de mim, sustentou-me e educou-me.

- Só?

- Acha pouco? É porque você não sabe o esforço que isso custou. Maior que o seu para obter S. Bernardo. E o que é certo é que d. Glória não me troca por S. Bernardo. (RAMOS, 1990, p. 115)

Madalena conta a pobreza em que viviam e Paulo Honório chega a se impressionar, mas não muda de opinião em relação à tia da esposa. Nota-se que, no trecho abaixo, Paulo Honório utiliza a locução verbal "pode ser", o que demonstra que sua linguagem vai ficando cada vez mais incerta:

Calei-me - e não senti nenhuma simpatia à pobre d. Glória. Continuei a julgá-la uma velha bisbilhoteira [...] E, para não descontentar Madalena:

- Pode ser que você tenha razão. [...] (RAMOS, 1990, p. 117, grifo nosso)

Porém, numa reflexão após uma briga com Madalena, Paulo Honório reconhece o valor do esforço de D. Glória: “O meu desejo era pegar Madalena e dar-lhe pancada até no céu da boca. Pancada em d. Glória também, que tinha gasto anos trabalhando como cavalo de matuto para criar aquela cobrinha." (RAMOS, 1990, p. 137, grifo nosso). Portanto, Paulo 


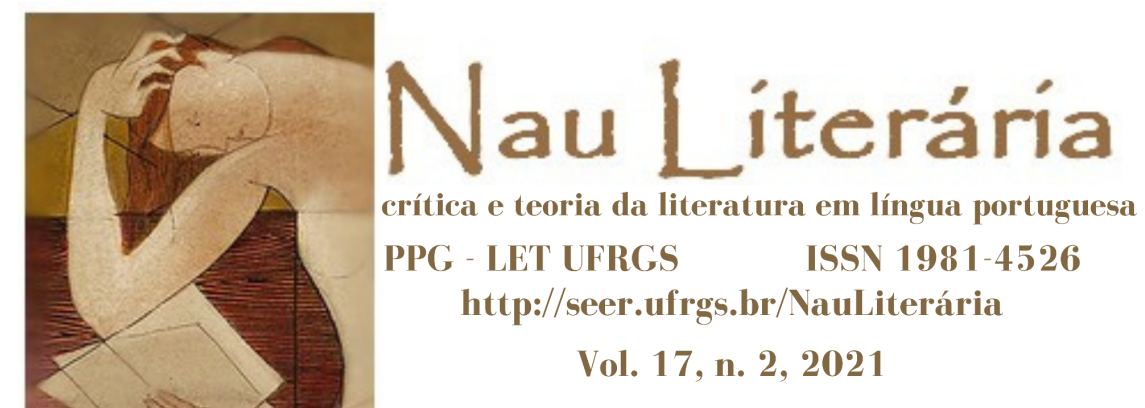

Honório ouve Madalena, mas só internaliza suas palavras em momento posterior ao momento da enunciação.

Em ambos os romances, o tempo é quantificado numa relação direta com o dinheiro e com a quitação de dívidas. De certa maneira, podemos dizer que todos os romances de Balzac possuem essa ligação. Assim como no romance de Graciliano Ramos, o tempo é quantificado de acordo com a data de vencimento de qualquer dívida, embora diversas vezes não seja marcado com precisão, ao contrário de São Bernardo. Uma de nossas hipóteses que poderia justificar a falta de marcação temporal é que em Balzac o tempo seria um agente que passaria sem ser percebido. Já em Graciliano Ramos, a passagem do tempo, ainda que seja contada com precisão até um dado momento, é o agente do declínio de energia vital. O processo de corrosão também ocorre sem ser notado pelo sujeito.

Ao narrar a compra da fazenda, Paulo Honório deixa claro que, mesmo num dia de chuva torrencial, ele precisa cobrar de Luís Padilha o dinheiro que lhe emprestou. A perseverança de Paulo Honório é característica de sua condição de empreendedor que planeja e executa: "A última letra venceu num dia de inverno. Chovia que era um deus-nos-acuda. De manhã cedinho mandei Casemiro Lopes selar o cavalo, vesti o capote e parti. Duas léguas em quatro horas. O caminho era um atoleiro sem fim.” (RAMOS, 1990, p. 20). Padilha, porém, não se preocupa e usa a chuva como desculpa para o adiamento do pagamento da dívida: “Eu tenho pensado nesse negócio, tenho pensado muito. Até perdi o sono. Ontem amanheci com vontade de lhe aparecer, para combinar. Mas não pude. Semelhante chuva...” (RAMOS, 1990, p. 23). Paulo Honório rebate: “- Deixemos a chuva.” (RAMOS, 1990, p. 23).

O diálogo entre Paulo Honório e Padilha demonstra a perseverança do primeiro em contraste com a procrastinação do segundo. Mesmo num dia de chuva forte, Paulo Honório precisa cobrar a dívida. Ele percorre, rapidamente, a cavalo, considerando que a estrada estava um "atoleiro sem fim", um percurso que poderia ser medido entre doze e quatorze quilômetros em quatro horas. Padilha, por sua vez, diz que não pode quitar sua dívida devido à chuva. Paulo Honório recusa a desculpa e deixa a chuva de lado, que para ele não foi 


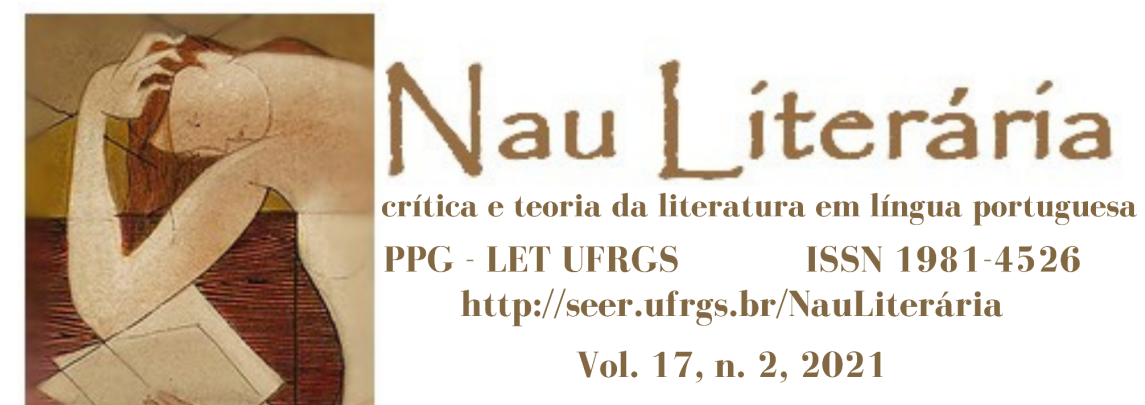

impedimento para cobrar a dívida. A procrastinação de Padilha pode ser demonstrada no texto pelo uso das reticências que, inclusive, nunca são usadas por Paulo Honório. As reticências demonstram a indefinição, algo em aberto, o que não condiz com o discurso direto, disciplinado e preciso de Paulo Honório.

No romance de Balzac, Rastignac está desesperado para conseguir dinheiro, para comprar roupas e sapatos, a fim de frequentar a sociedade, e pede ajuda à família. No momento em que chegam suas encomendas, Vautrin dá uma gorjeta ao entregador: "Vautrin fez o gesto de apontar a arma para o adversário. Rastignac quis dar uma gorjeta ao carregador e não achou nada no bolso. Vautrin meteu a mão no seu e atirou vinte soldos ao homem." (BALZAC, 2012, p. 127). Rastignac paga Vautrin, mas não há uma indicação de quanto tempo ele demorou para saldar a dívida. É interessante notar a violência presente nos gestos de Vautrin: "apontar a arma para o adversário" e "atirar" vinte soldos ao carregador. Aparentemente, Vautrin está tentando coagir Rastignac de alguma maneira, fazendo com que o jovem tenha medo dele e aceite sua proposta infame para enriquecer.

Embora em muitos momentos Balzac não explicite o tempo exato, o vencimento das dívidas é um tema muito recorrente em seus romances. Depois de ler a carta da mãe, que lhe enviara o dinheiro pedido, Rastignac se lembra do velho Goriot retorcendo objetos de prata para pagar as dívidas da filha: "Quando Eugênio acabou de ler a carta, estava banhado em lágrimas. Pensava no pai Goriot retorcendo seus utensílios de prata dourada para pagar a letra de câmbio da filha.” (BALZAC, 2012, p. 121).

Como exemplo - quase único - de um tempo marcado com precisão e relacionado ao vencimento de dívidas, há a cena em que Rastignac é incitado por Vautrin a assinar uma letra de câmbio:

Não quer dever-me favores, hein? - acrescentou Vautrin, deixando escapar um sorriso. - Pois não seja essa a dúvida. Fique com este dinheiro e escreva o seguinte - acrescentou, tirando um selo da carteira: - Recebi a quantia de três mil e quinhentos francos, que pagarei no prazo de um ano. Date e assine! O juro é bastante elevado para que você não tenha escrúpulos de aceitar. (BALZAC, 2012, p. 193) 


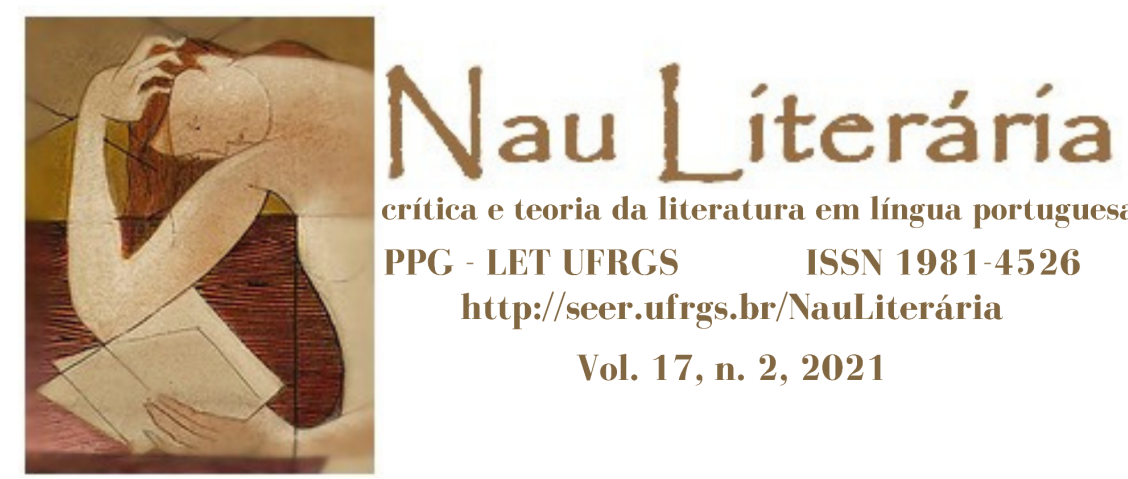

Em São Bernardo, o tempo é quantificado com precisão até o momento decisivo da morte de Madalena. A partir daí, o entusiasmo e a força de Paulo Honório se esgotam aos poucos. O tempo do relógio passa a não ser mais contado:

O que não percebo é o tique-taque do relógio. Que horas são? Não posso ver o mostrador assim às escuras. Quando me sentei aqui, ouviam-se as pancadas do pêndulo, ouviam-se muito bem. Seria conveniente dar corda ao relógio, mas não consigo mexer-me. (RAMOS, 1990, p. 104)

Antes de se casar com Madalena, Paulo Honório demonstra toda a sua pressa em concluir a negociação do casamento com a moça: “- Um ano? Negócio com prazo de um ano não presta. Que é que falta? Um vestido branco faz-se em vinte e quatro horas." (RAMOS, 1990, p. 93). Aqui, o Paulo Honório disciplinado, negociador, calculista e "explorador feroz" (RAMOS, 1990, p. 183) demonstra toda a sua força e rapidez em sua relação com o tempo: os trezentos e sessenta e cinco dias, oferecidos por Madalena, são reduzidos a apenas um dia. $\mathrm{O}$ Paulo Honório, derrotado pela morte de Madalena e vencido pelo tempo, nem consegue mais se levantar para dar corda ao relógio e o dínamo emperra-se. No fim do romance, ele só quer dormir por alguns minutos, assim, a precisão desaparece definitivamente.

O momento decisivo em $O$ pai Goriot - a morte do velho Goriot -, ao contrário, parece dar mais força para Rastignac, que resolve lutar contra a sociedade parisiense. Porém, antes desse momento, Rastignac também começa a se cansar. Ao entender como a sociedade funciona, por meio do momento decisivo do romance, Rastignac torna-se mais forte, mais disposto a negociar e a participar em seu jogo com a sociedade:

Dois coveiros, depois de atirarem algumas pás de terra em cima do caixão [em que jazia o pai Goriot], para ocultá-lo, ergueram-se, e um deles, dirigindo-se a Rastignac, pediu uma gorjeta. Eugênio revistou os bolsos e, não tendo encontrado nada, foi obrigado a pedir vinte soldos emprestados a Cristóvão. Esse fato, tão insignificante em si mesmo, causou a Rastignac um terrivel acesso de tristeza. Caía a tarde. Um crepúsculo úmido irritava os nervos. Eugênio contemplou a sepultura [de Goriot] e enterrou nela sua derradeira lágrima de rapaz, aquela lágrima arrancada pelas puras emoções de um coração puro, uma dessas lágrimas que, da terra onde caem, se elevam até o céu. Cruzou os braços e admirou as nuvens. Vendo-o nessa atitude, Cristóvão o deixou.

Ficando só, Rastignac encaminhou-se para a parte alta do cemitério e de lá viu Paris, tortuosamente deitada ao longo das duas margens do Sena, onde as luzes começavam a brilhar. Seus olhos fixaram-se quase avidamente entre a coluna da Place Vendôme e os Invalides, no ponto em que vivia aquela bela sociedade na qual quisera penetrar. Lançou àquela colmeia 


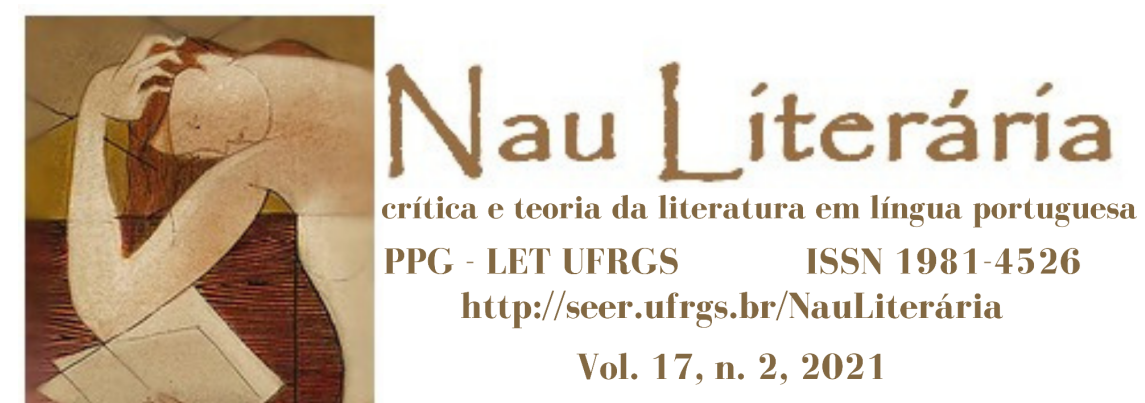

sussurrante um olhar que parecia sugar-lhe antecipadamente o mel e proferiu esta frase suprema:

- Agora, é entre nós dois!

E como num primeiro ato de desafio à sociedade, Rastignac foi jantar à casa da sra. de Nucingen. (BALZAC, 2012, p. 321, grifo nosso)

Rastignac, após enterrar junto com o pai Goriot sua "última lágrima de rapaz", percebe, vendo a cidade de Paris do alto, unindo, portanto, a parte rica e a parte pobre, que uma parte sustenta a outra. A partir desse momento, Eugène está anestesiado contra a repulsão que sente pela forma com a qual se deve negociar com a sociedade para realizar seus desejos. Com o desafio lançado, seu primeiro ato é jantar na casa da sra. de Nucingen, Delphine, filha do pai Goriot, a quem despreza.

Mas Eugène aprendeu, com Vautrin, que é necessário fazer qualquer coisa para alcançar seus objetivos: "Humilha-te, suporta tudo! [...] Cada um por si, não é? [...] Como diz Vautrin, preciso transformar-me num projétil de artilharia." (BALZAC, 2012, p. 149, grifo nosso). Além disso, vemos que um pequeno detalhe é o que provoca o desafio final: Eugène não tem dinheiro para dar uma gorjeta ao coveiro. Dessa maneira, podemos notar, no romance de Balzac, a presença do elemento mínimo se que se torna o ponto de virada da narrativa.

A cena de Paulo Honório subindo na torre da igreja, contemplando a fazenda, e a cena de Rastignac lançando o desafio a Paris são semelhantes. Em São Bernardo, o detalhe da "boneca traçando linhas invisíveis num papel” é o que modifica tudo no romance de Graciliano Ramos:

Ali pelos cafus desci as escadas, bastante satisfeito. Apesar de ser indivíduo medianamente impressionável, convenci-me de que este mundo não é mau. Quinze metros acima do solo, experimentamos a vaga sensação de ter crescido quinze metros. E quando, agigantados, vemos rebanhos numerosos a nossos pés, plantações estirando-se por terras largas, tudo nosso, e avistamos a fumaça que se eleva de casas nossas, onde vive gente que nos teme, respeita e talvez até nos ame, porque depende de nós, uma grande serenidade nos envolve. Sentimo-nos bons, sentimo-nos fortes. E se há ali perto inimigos morrendo, sejam embora inimigos de pouca monta que um moleque devasta a cacete, a convicção que temos da nossa fortaleza torna-se estável e aumenta. Diante disto, uma boneca traçando linhas invisíveis num papel apenas visível merece pequena consideração. (RAMOS, 1990, p. 156, grifos nossos) 


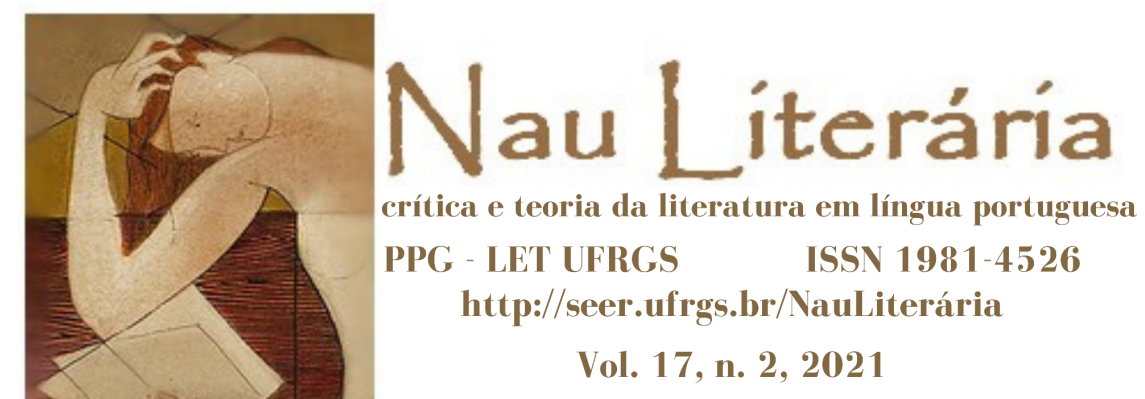

Enquanto Paulo Honório tem um momento de delírio, usando um discurso completamente diferente do que ele usava antes, por meio do uso da primeira pessoa do plural que, aliás, é uma das únicas vezes em que o "nós" aparece em toda a obra quando Paulo Honório refere-se a ele mesmo, Rastignac demonstra o máximo de sua lucidez ao compreender, finalmente, o funcionamento da sociedade na qual deseja entrar.

$\mathrm{O}$ detalhe, que faz toda diferença, é discutido tanto por Moretti quanto por Rancière. Enquanto Rancière liga o detalhe à "democracia na literatura", Moretti faz essa mesma relação usando as concepções burguesas de tempo. O enchimento, tratado por ambos os autores, mas com nomes e abordagens diferentes, relaciona-se com o efeito mortificante no romance, pois os enchimentos, ou os detalhes, nos dão pistas sobre seu desfecho. O efeito mortificante é o cansaço que o personagem do romance vivencia quando todos os pequenos fatos se condensam e produzem sua "semana fatal" ou sua "penca de caiporismos".

\section{A passagem da dominação ao descontrole: o efeito corrosivo do tempo}

Podemos concluir que o tempo está intimamente ligado ao dinheiro, tanto em $O$ pai Goriot quanto em São Bernardo. O romance de Graciliano Ramos aparenta ser a compressão do romance realista do século XIX e do romance modernista do século XX por sua forma de tratar do tempo, embora haja diferenças quanto à demarcação precisa da passagem temporal, e pela recuperação de alguns tópicos do romance do século XIX. Balzac usa a data de vencimento das letras de câmbio para marcar o tempo no romance, porém ele não é tão preciso quanto Graciliano.

O esfriamento do entusiasmo de Paulo Honório é revelado por meio de seu descontrole em relação ao tempo após a morte de Madalena. O tempo, em São Bernardo, até o momento decisivo, é controlado por Paulo Honório, mas Rastignac ainda não tem esse domínio. Em Balzac, a aparente falta de controle denota, ainda assim, a passagem temporal no caminho de aprendizagem que Rastignac percorre ao longo do romance. Talvez Eugène não domine ainda o tempo porque ele ainda não detém e não domina o dinheiro. Em ambos os casos, o tempo é 


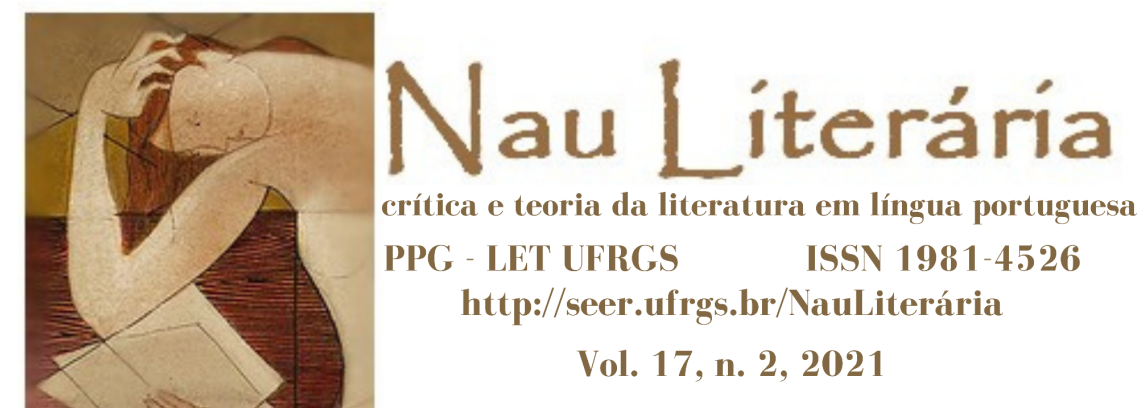

também o agente da corrosão da energia vital, mas é também o agente da força enquanto for equivalente ao dinheiro. Ambos caminham lado a lado.

A frase "tempo é dinheiro" aplica-se em ambos os romances. O controle e a disciplina, próprios do século XIX burguês, estão presentes na obra de Graciliano Ramos de forma latente. O efeito mortificante, o efeito da corrosão do tempo, que derrota Paulo Honório, é típico do romance do final do século XIX. Rastignac, contudo, parece inverter um pouco a lógica e termina o romance com um desafio à cidade em um tom confrontativo.

É interessante notar que o romance de Balzac tem um final em aberto - como, aliás, na maioria de seus romances. Não sabemos qual será o fim de Rastignac, a não ser que leiamos toda a obra de Balzac. O fim em aberto cria a possibilidade de se notar que o mundo é um infinito de possibilidades: a conclusão com recompensas e com castigos, dados pela figura de autoridade, assim como na epopeia homérica, não existe mais no mundo balzaquiano. Assim, Rancière parece ter razão ao dizer que a ficção moderna não tem um fim. O final de $O$ pai Goriot é como um acorde dissonante devido à discrepância entre o tom do penúltimo e do último parágrafo. Rastignac reconhece que o mundo é terrível, mas o jovem tem força para jogar com ele. A partir do enterro de sua última lágrima da juventude, Eugène não questionará mais as regras do jogo como fazia a todo instante, pois percebe que a justiça não importa mais. Dessa forma, a educação social e sentimental pela qual passa ao longo do romance chega ao fim.

A concepção de tempo e de espaço na sociedade burguesa está relacionada com a “democracia das sensações" que possibilita ao povo experimentar experiências que até então não lhe pertencia. A forma mais horizontal do tratamento das pessoas, que surge após a Revolução Francesa, possibilita a definição de uma nova identidade ao sujeito moderno. A fragmentação do sujeito, as tentativas de definição de sua identidade e sua constante formação aparece já em Balzac e é explorada ao máximo por Graciliano Ramos.

Rastignac é um jovem em formação e Paulo Honório é um sujeito de meia idade. Ambos têm identidades fragmentadas e estão em contínuo movimento. Enquanto o primeiro 


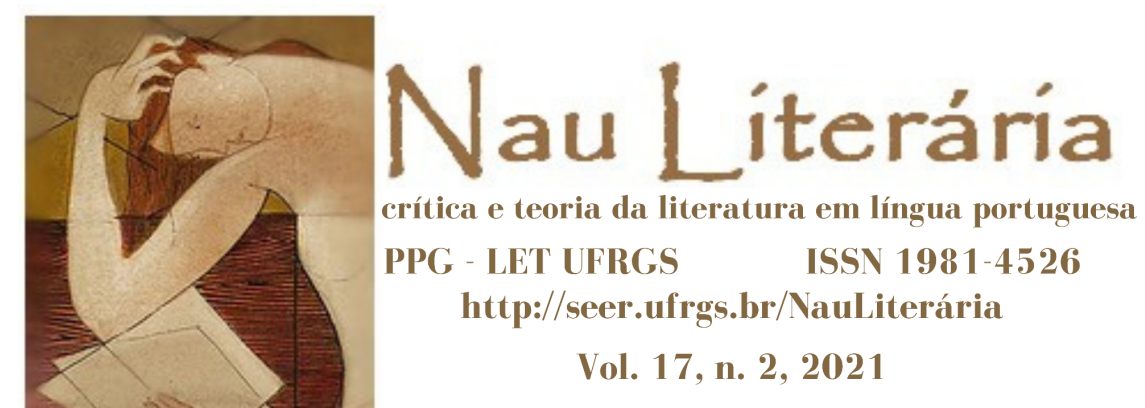

propõe-se a ser o "projétil de artilharia" e mostra toda a sua força e disposição para confrontar a sociedade no final do romance, o segundo - que já fora esse projétil - perde todo o seu entusiasmo, é vencido, devido à ação do tempo e à morte de Madalena, torna-se o "dínamo emperrado" e só deseja descansar alguns minutos.

Com o descontrole de Paulo Honório em relação ao tempo revela-se também seu aparente descontrole em relação ao dinheiro. Quando menciona que os bancos fecharam as portas para ele, à primeira vista, parece que Paulo Honório perdeu o controle sobre seu dinheiro e não honrou os pagamentos, apesar de dizer que isso nunca aconteceu. Contudo, podemos inferir que, na verdade, ele possa ter percebido que não tem o controle total de seu destino como pensava, pois há circunstâncias maiores do que ele e que têm o poder de colocá-lo em uma situação de passividade.

Rastignac, ao contrário, não perde o controle: ele assume o controle de sua vida, justamente no momento crítico do romance, percebendo que está por sua própria conta. A tentativa de dominação da sociedade pode ser encarada também como uma tentativa de dominação do tempo e do dinheiro. Contudo, “[...] o tempo é um jogador que ganha, sem furtar, cada jogada [...]" (BAUDELAIRE, 2012, p. 51-53), como afirma Baudelaire em "O relógio". Restará a Rastignac apenas domar a colmeia sussurrante na qual entrará como um projétil de artilharia.

\section{Referências}

ANDRADE, Carlos Drummond de. Elegia. In: . Antologia poética. São Paulo: Record, 2001, p. 336.

AUDEN, Wystan Hugh. História de detetive. In: João Moura JR. São Paulo: Companhia das Letras, 2013, p. 53. Poemas. Trad. José Paulo Paes e

BALZAC, Honoré de. O pai Goriot. In: . A comédia humana (vol. 4). Trad. Gomes da

Silveira. São Paulo: Globo, 2012. 


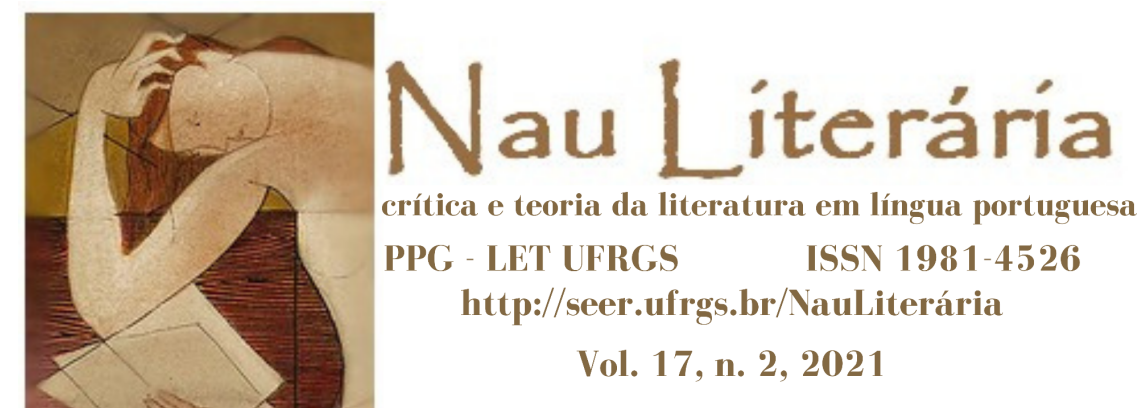

BALZAC, Honoré de. Ilusões perdidas. In: Ernesto Pelanda e Mario Quintana. São Paulo: Globo, 2013. A comédia humana (vol. 7). Trad.

BAUDELAIRE, Charles. O relógio. In: . As flores do mal. Trad. Ivan Junqueira. Rio de Janeiro: Nova Fronteira, 2012, p. 51-53.

EVANS-PRITCHARD, Edward Evan. Tempo e espaço. In: . Os Nuer: uma descrição do modo de subsistência e das instituições políticas de um povo nilota. Trad. Ana M. Goldberger Coelho. São Paulo: Perspectiva, 2007, p. 107-150.

GRAEBER, David. Idade dos Grandes Impérios Capitalistas (1450 d.C. - 1971 d.C.). In:_ Dívida: os primeiros 5.000 anos. Trad. Rogério Bettoni. São Paulo: Três Estrelas, 2016, p. 388-453.

HALL, Stuart. A identidade cultural na pós-modernidade. Trad. Tomaz Tadeu da Silva e Guacira Lopes Louro. Rio de Janeiro: DP\&A, 2006.

MELO NETO, João Cabral de. Para mascar com chiclets. In: . A educação pela pedra e outros poemas. Rio de Janeiro: Objetiva, 2008, p. 263-264.

KOSELLECK, Reinhart. Estratos do tempo: estudos sobre história. Trad. Markus Hediger. Rio de Janeiro: Contraponto; PUC-Rio, 2014.

MORETTI, Franco. O burguês: entre a história e a literatura. Trad. Alexandre Morales. São Paulo: Três Estrelas, 2014.

RAMOS, Graciliano. São Bernardo. Rio de Janeiro: Record, 1990.

RANCIÉRE, Jacques. O fio perdido: ensaios sobre a ficção moderna. Trad. Marcelo Mori. São Paulo: Martins Fontes, 2017.

THOMPSON, Edward Palmer. Tempo, disciplina de trabalho e o capitalismo industrial. In:__ Costumes em comum: estudos sobre a cultura popular tradicional. Trad. Rosaura Eichemberg. São Paulo: Companhia das Letras, 1998, p. 267-304. 